\title{
Editorial endeavours: Plainchant revision in early modern Italian printed graduals*
}

\section{Abstract}

The extensive melodic revision of plainchant in editions of the Graduale Romanum published in Italy from the late sixteenth century onward resulted in musically diverse repertoires that could depart widely from earlier chant traditions. The scale of the changes in these sources, both in type and in number, has obscured certain aspects of their editors' work: their familiarity with the corpus, their aims and techniques, and their approach to the task. Previous analyses concluded that the editors worked on a chant-by-chant basis, and were either unaware of or ignored any shared melodic relationships between pieces of plainchant. An examination of the revisions to the recurrent melody used by the eight Ostende alleluias in three influential Italian printed gradualsGardano 1591, Giunta 1596, and Medici 1614/15 — provides a different perspective. Analyses of the reshaped chants reveal that the editors possessed knowledge of the repertoire, guiding aims, and favoured revision techniques. The combination of these factors, whether intentionally or not, resulted in the chants' continued structural connection in the midst of increased melodic diversity. The individuation evident the chants did not necessarily signal the editors' unfamiliarity with the repertoire, but could have been indicative of their intentional rejection of

\footnotetext{
* This article is based upon research in my doctoral dissertation, "'Diligentissime emendatum, atque correctum”? The transmission and revision of plainchant in Italian printed graduals, 1499-1653" (PhD dissertation: The University of Manchester, 2015). I would like to thank Professor David Burn, Dr. Amy Chambers, and Dr. Miriam Wendling for the comments on earlier versions of this article. My current research is funded by the Fonds Wetenschapelijk Onderzoek - Vlaanderen (FWO).
} 
shared elements. Further, the revisions to the Ostende alleluias reveal that the editorial process could be flexible, with the chants approached both as individual entities and as groups. These findings demonstrate the complexity of the editorial process in early modern Italian printed graduals, and deepen our understanding of this multifaceted repertoire.

\section{Introduction}

In the final decades of the sixteenth century, the editors of Italian printed graduals entered a period of industrious activity. The first phase was the collation of the contents of editions of the Graduale Romanum with the newly issued Missale Romanum (1570), which had been revised at the behest of the Council of Trent (1545-1563). The liturgical changes were mostly incorporated by 1580 , but did not provoke large-scale alterations to the plainchant melodies. ${ }^{1}$ Ongoing calls for musical reform, which included a rescinded papal commission for restored liturgical chant books, inspired Italian publishers to embark on a new phase of publications. ${ }^{2}$ Within twenty-five years, four separate revisions of the entire Graduale Romanum were carried out for the Venetian firms of Gardano (1591) and Giunta (1596, revised 1606), and the Roman firm of Medici (16141615). Other Italian publishing firms drew upon these prints—especially those by Giunta—when

\footnotetext{
${ }^{1}$ Marianne C.E. Gillion, 'Cantate Domino Canticum Novum? A Re-examination of 'Post-Tridentine' Chant Revision in Italian Printed Graduals', in Violet Soen and Wim François (eds.), The Council of Trent: Reform and Controversy in Europe and Beyond (1545-1700), 3 vols. (Göttingen, 2018), 3:159-81.

${ }^{2}$ Gillion, "'Shall the dead arise and praise you"? Revisions to the Missa pro defunctis in Italian printed graduals, 1591-1621', Trossinger Jahrbuch für Renaissancemusik 13 (2014; published 2017), 59-80; here at 60-63.
} 
they created their own revised editions. ${ }^{3}$ The concise, sculptured melodies in the graduals depart quite substantially from the pre-existent printed plainchant tradition. Analyses have revealed that while the editors shared a broad set of aims, they differed in their aesthetic and music-theoretical priorities, which led to musically diverse results. ${ }^{4}$ The sheer scale of the task and the diversity of the resultant changes has raised questions concerning the editors' knowledge of the corpus and their methodologies of revision.

Previous scholarship concluded that chant editors worked on a chant-by-chant basis, with little concern—or perhaps little knowledge—of the melodic relationships that existed within the repertoire. In his sweeping study of graduals printed in Europe between 1591 and 1800, An Introduction to the Post-Tridentine Mass Proper, Theodore Karp assessed the editorial processes through revisions to several formulaic graduals, tracts and alleluias. He found that editors did not alter related chants in related fashions. However, his sample, while broad in geography, chronology, and number of editions, was limited in the number of chants concerned. ${ }^{5}$ Richard Sherr, in his review of Karp's book, questioned whether the editors would have been aware of the families of formulaic chants, and observed that chant editors were not necessarily chant scholars. ${ }^{6}$ Yet in his research into the gradual published by Gardano in 1591, which was edited by the composers and churchmen Ludovico Balbi, Orazio Vecchi, and Andrea Gabrieli, Marco Gozzi

${ }^{3}$ Gillion, 'Retrofitting plainchant: The incorporation of "Tridentine" liturgical changes in Italian printed graduals, 1572-1653', The Journal of Musicology 36, no. 3 (forthcoming 2019).

${ }^{4}$ Theodore Karp, An Introduction to the Post-Tridentine Mass Proper, 2 vols. (Middleton, 2005), 1:203-4; Gillion, 'Shall the dead arise', 64-65.

${ }^{5}$ Karp, Post-Tridentine, 1:88-93; 113-19; 167-78.

${ }^{6}$ Richard Sherr, 'The life of plainchants: A review of An Introduction to the Post-Tridentine Mass Proper by Theodore Karp', Early Music, 35.2 (2007), 301-2; here at 302. 
reached similar conclusions to Karp. Gozzi found no evidence of forward planning and an overall design. ${ }^{7}$ In contrast, recent investigations of the revisions made to eighth-mode tracts in Italian printed graduals has indicated that the editors were, to differing extents, aware of and responsive to their formulaicism. ${ }^{8}$ Due to the parameters of these studies, the authors could not investigate how the editors addressed an entire family of formulaic chants. Analyses of the revisions to the Ostende-type alleluias in a core group of Italian printed graduals issued between 1591 and 1615 provides new information concerning the editors' knowledge of and approach to the plainchant repertoire. The modifications reveal overarching aesthetic plans, consistent techniques, guiding priorities, and an awareness of the repertoire. The findings thus enhance our understanding of the editors and of the music they so assiduously recreated.

Early modern plainchant: Perceived problems and printed solutions

In the opinion of many, early modern plainchant was in a deplorable state: it conformed neither with contemporary theoretical precepts, nor with the prevailing musical aesthetic. Theorists and churchmen decried incorrect Latin accentuation, poor pronunciation, and ludicrous performance practices that detracted from reverent liturgical celebrations. ${ }^{9}$ Chant revision was carried out in

\footnotetext{
${ }^{7}$ Marco Gozzi, 'L’edizione veneziana del Graduale curate da Vecchi, Balbi e Gabrieli (1591)', Polifonie 5.1 (2005), 9-31; English translation: 'The Venetian edition of the Gradual edited by Gabrieli, Balbi, and Vecchi', 33-46; here at 41.

${ }^{8}$ Gillion, 'Shall the dead arise', 72-77; Gillion, 'Cantate domino', 170-76.

${ }^{9}$ For an overview of some of the complaints see: Don Harrán, Word-Tone Relations in Musical Thought (Neuhausen-Stuttgart, 1986), 113-19, 123-9, 184-5, 209-10, 294-5; Harrán, In Defense of Music: The Case for Music as Argued by a Singer and Scholar of the Late Fifteenth Century (Lincoln, 1989); Mother Thomas More,
} 
Italian printed graduals throughout the sixteenth century, but the repertoire continued to be perceived as problematic. ${ }^{10}$ Its condition even garnered papal disapproval. Pope Gregory XIII, who in 1577 commissioned composers Giovanni da Palestrina and Annibale Zoilo to revise liturgical chant books wrote that they were 'filled to overflowing with barbarisms, obscurities, contrarieties, and superfluities as a result of the clumsiness or negligence or even wickedness of the composers, scribes, and printers' ${ }^{11}$ Yet the desire for a revision of the chant corpus was tempered by practical considerations. Theorists acknowledged that, for all its prosodic errors, plainchant stood outside the rules of grammar and could thus be left unaltered. ${ }^{12}$ The cost of financing new liturgical books probably led Philip II of Spain to (successfully) pressure Gregory XIII to withdraw his support from the Roman chant revision project. ${ }^{13}$ The larger political ramifications of the abolition of local chant traditions in favour of an official gradual could also have influenced his decision. Although the pontifical plans for a revised Graduale Romanum were discarded, the idea would eventually be taken up by ambitious publishers.

\footnotetext{
'The Performance of Plainsong in the Later Middle Ages and the Sixteenth Century', Proceedings of the Royal Musical Association, 92 (1965-6), 121-4; here at 121-23.

${ }^{10}$ Gillion, 'Diligentissime emendatum, atque correctum'.

${ }^{11}$ The full Latin text of the commission is found in Raphael Molitor, Die Nach-Tridentinische Choral-Reform zu Rom: Ein Beitrag zur Musikgeschichte des XVI. und XVII. Jahrhunderts, 2 vols. (Leipzig, 1901-2; reprinted Hildesheim, 1967), 1:297-8. English translation taken from Oliver Strunk and Leo Treitler (eds.), Source Readings in Music History, rev. ed. (New York, 1998), 375 (full translation: 375-76).

${ }^{12}$ Harrán, Word-Tone Relations, 115-17, 204-5.

${ }^{13}$ The correspondence is found in Molitor, Die Nach-Tridentinische Choral-Reform, 1: 296-7, 301-5. For English translations: Robert F. Hayburn, Papal Legislation on Sacred Music 95 A.D. to 1977 A.D. (Collegeville, 1979), $38-43$.
} 
The Italian producers of liturgical chant books were attuned to the needs of the lucrative religious market. In the final decades of the sixteenth century, their first priority was not to revise plainchant, but to produce graduals with contents that conformed with the newly restored and universally imposed Missale Romanum (1570). ${ }^{14}$ The process of collation required modifications to certain chants, but apart from these, the melodies remained untouched. ${ }^{15}$ However, in 1587 Angelo Gardano issued a small combined Franciscan gradual/antiphoner, edited by Balbi. ${ }^{16}$ This was followed in 1591 by a full Graduale Romanum with extensively altered plainchant melodies. ${ }^{17}$ According to the volume's preface, these resulted from the collective and individual efforts of Balbi, Vecchi, and Gabrieli. ${ }^{18}$ The publication of the Gardano graduals marked the beginning of a new phase of plainchant revision. The powerful firm of Giunta issued a Graduale Romanum, amended by an anonymous editor, in 1596. The melodies were further modified in the firm's subsequent edition in 1606. The Medicean Press in Rome published a Vaticancommissioned, but not Vatican-sanctioned Graduale Romanum between 1614 and 1615. In

\footnotetext{
${ }^{14}$ The revised Missale Romanum was universally imposed unless an institution or a region could prove the use of a rite extending back 200 years or more.

${ }^{15}$ Gillion, 'Retrofitting plainchant'.

${ }^{16}$ Marco Gozzi, 'The Venetian edition', 40-43; Richard J. Agee, 'Ideological Clashes in a Cinquecento Edition of Plainchant' in Ann Buckley and Cynthia J. Cyrus (eds.), Music, Dance and Society: Medieval and Renaissance Studies in Memory of Ingrid G. Brainard (Kalamazoo, 2011), 143-58; here at 143-46.

${ }^{17}$ Ibid. See also: Annarita Indino, 'Il Graduale stampato da Angelo Gardano (1591)' in Giulio Cattin, Danilo Curti and Marco Gozzi (eds.), Il canto piano nell'era della stampa: atti del Convegno internazionale di studi sul canto liturgico nei secoli XV-XVIII: Trento, Castello del Buonconsiglio, Venezia, Fondazione Ugo e Olga Levi, 9-11 Ottobre 1998 (Trent, 1999) 207-21.

${ }^{18}$ Graduale Romanum (Venice: Gardano, 1591), fol. 2r. The division of editorial labour will be discussed further below.
} 
preparation for 20 years, the gradual was edited by the composers Francesco Soriano and Felice Anerio, the remnants of a six-man committee. ${ }^{19}$ These four publications - but especially the two by Giunta — shaped printed plainchant traditions in Italy through the mid-seventeenth century due to a long-established pattern of production.

Venetian liturgical book publishers worked within a framework of interrelation, which influenced their activities and those of their chant editors. In contrast to the situations elsewhere in Europe, graduals were rarely commissioned by prelates, but financed by the printers. ${ }^{20}$ Instead of having an exemplar provided to use as a copytext, the publishers needed to source one themselves. In order to save time and money, firms commonly copied the layouts and even the contents of their previous editions as a time-saving measure. They also drew heavily upon each other's material, either in an act of collaboration or piracy. ${ }^{21}$ Yet the relationship between these prints extended beyond mere copying, as becomes clear when their musical contents are

${ }^{19}$ Giacomo Baroffio and Manlio Sodi (eds.), Graduale de Tempore iuxta ritum Sacrosanctae Romanae Ecclesiae: Editio Princeps (1614) (Vatican City, 2001); Ibid., Graduale de Sanctis iuxta ritum Sacrosanctae Romanae Ecclesiae: Editio Princeps (1614-15) (Vatican City, 2001); Giacomo Baroffio, 'La tranmissione delle melodie gregoriane nell'Editio Medicea e nelle fonti parallele', Polifonie 6.2 (2006), 11-41; English translation, 'The transmission of Gregorian melodies in the Editio Medicea and parallel sources', 43-52.

${ }^{20}$ Magnus Williamson, 'Affordable splendor: editing, printing and marketing the Sarum Antiphoner (1519-20)', Renaissance Studies 26.1 (2012), 60-87; Gillion, ‘Archiepiscopal Archetypes, Printed Books, and Parish Practices: Musical Notation in Editions of the Missale Salisburgense (1492-1515)', Florilegium (forthcoming 2019).

${ }^{21}$ Richard J. Agee, 'The Printed Dissemination of the Roman Gradual in Italy During the Early Modern Period', Notes 64.1 (2007), 9-42; here at 10-15. 
analysed. $^{22}$ The appropriation of competitors' material is evidenced by shared melodic readings, and its adaptation by significant, systematic variants. ${ }^{23}$ These cover a wide spectrum, including alterations to orthography and text underlay, the notation of accidentals and pause lines, and melodic changes. Their regular occurrence within a source is indicative of an intentional act of revision, however seemingly slight, carried out by a musically literate editor, even when none is named in the print. By the end of the sixteenth century the use of previous printed graduals as copytexts was an established practice, and chant revision an ongoing phenomenon. ${ }^{24}$ Therefore, the methods and techniques of previous generations of editors were employed and expanded by their seventeenth century successors.

In their approach to the plainchant repertoire, the editors of Italian printed graduals were influenced by prevailing aesthetic ideas and theoretical standards. They projected these onto the

${ }^{22}$ Karp begins to explore the melodic relationships between the Italian printed graduals in Post-Tridentine, 1:8, 86, 202. The relationships between editions of the gradual issued in Italy between 1499 and 1653 , and the formation of identifiable printed plainchant traditions are discussed in detail in Gillion, 'Dilegentissime emendatum', Chapter Two.

${ }^{23}$ Some variants stemmed from typesetting errors or flexible notational practices. However, the frequency of any given variant throughout a source, combined with its context (i.e., if it resolves a musically problematic reading) indicates that the modification was a conscious change. On the importance of small variants in manuscript chant sources see: Andrew Hughes, 'Patterns and paleography: revisions, variants, errors, and methods' in Terence Bailey and Alma Santosuosso (eds.), Music in Medieval Europe: Studies in Honour of Bryan Gillingham (Aldershot, 2007), 287-311; here at 289-90, 298-302.

${ }^{24}$ Gillion, 'Diligentissime emendatum'. This does not preclude the use of manuscript copytexts, but no direct evidence of their use has been found in Venice. In contrast, analyses have shown that editors could use up to four different printed exemplars. Gillion, 'Retrofitting plainchant'. 
past, and reconfigured the chant according to contemporary standards. ${ }^{25}$ Conjectural emendation was a normative editorial approach in early modern Italy; cautious approaches, high-quality exemplars, and circumspect speculation were atypical. ${ }^{26}$ The overarching aims of early modern chant editors have been imputed through analyses of their revised plainchant. Several main techniques were used to modify the chants: melodies were shortened and recast through the removal and addition of notes, accidentals more frequently applied, the text underlay modified, and pause lines modified or excised. These alterations evince a desire for increased brevity, improved prosody, and modified text-music syntax, combined with a willingness to reshape the melodic line. ${ }^{27}$ Although the editors shared broad aims the importance assigned to them varied. For example, the excision notes from a melisma might increase its brevity, but not correct ungrammatical accentuation. In that instance, prosody would have been of lesser concern to the editor. The categorization and investigation of revision techniques reveals that adaptation patterns can be traced consistently in stylistically diverse genres throughout entire editions of the Graduale Romanum. This strongly suggests that the editors had overarching aesthetic plans guiding their work. ${ }^{28}$ The relative freedom with which they reworked plainchant, and its musically diverse results, has inadvertently obscured their knowledge of the repertoire and certain facets of their editorial processes.

\footnotetext{
${ }^{25}$ Karp, Post-Tridentine, 1: 1-3; Baroffio, 'The transmission of Gregorian melodies', 45.

${ }^{26}$ Brian Richardson, Print Culture in Renaissance Italy: The Editor and the Vernacular Text 1470-1600 (Cambridge, 1996), 20-23.

${ }^{27}$ Karp, Post-Tridentine, 1:203-4; Gillion, 'Shall the dead arise', 64-65.

${ }^{28}$ Specific examples can be found in Ibid., 66-77 (all genres of proper chants).
} 
The editors were responsible for revising a large and intricate repertoire in which a significant number of chants were interconnected through the use of shared melodic material. This is most evident in the use of formulas: recurrent musical patterns that generally end with a cadence and are usually tied to a semantic unit. ${ }^{29}$ These phrase-groups are thought to be linked to the oral transmission of plainchant, although the introduction of notation did not necessarily lessen their mnemonic function. ${ }^{30}$ The editors' treatment of these elements has been used to gain insight into their knowledge of the repertoire and their approaches to revision. Karp's analyses of a number of formulaic alleluias, graduals, and tracts in graduals printed throughout Europe from the late sixteenth through the nineteenth centuries led him to conclude that the editors worked on a chant-by-chant basis, disregarding the melodic relationships apparent in the repertoire. He linked this increased individuation to a change from an oral to a written culture. ${ }^{31}$ In his review of Karp's work, Sherr argued that by the early modern period formulaicism had lost its purpose; the editors of printed graduals might have been unaware of or simply ignored the formulas. ${ }^{32}$ Even if they were less mnemonically useful by the seventeenth century, which is debatable, formulas

\footnotetext{
${ }^{29}$ There exists some variability concerning the definition of the term 'formula', which is indicative of the variety of stylistic characteristics that could be (and have been) described as 'formulaic'. The definition used above is a combination of those found in: Rebecca Maloy, Inside the Offertory: Aspects of Chronology and Transmission (Oxford, 2010), 90-1; and Emma Hornby, Gregorian and Old Roman Eighth-Mode Tracts (Aldershot, 2002), 910.

${ }^{30}$ On the memorisation of (notated) plainchant in the late-medieval period see: Anna Maria Busse Berger, Medieval Music and the Art of Memory (Berkeley, 2005), 47-84, especially at 50; Craig Wright, Music and Ceremony at Notre Dame of Paris, 500-1550 (Cambridge, 1989), 325-29.

${ }^{31}$ Karp, Post-Tridentine, 1:88-93; 113-19; 167-78.

${ }^{32}$ Sherr, 'The life of plainchants', 302.
} 
remained an identifiable stylistic characteristic in plainchant. Recent research into the revisions to eighth-mode tracts in early modern Italian printed graduals has demonstrated that editors, to different degrees, recognized and responded to their constituent shared phrase groups. ${ }^{33}$ Further exploration of revisions to formulaic chants in these sources has the potential to clarify questions concerning their editors' knowledge of and approach to the repertoire.

Revising Formulacism: The Ostende alleluias

The Ostende-type alleluias, a group of chants that share the same melody, provide an ideal set of case-studies to investigate the editors' methodologies of revision. The eighth-mode Ostende nobis is the first alleluia of the liturgical year. ${ }^{34}$ The melody as notated in the first Graduale Romanum printed in the Italian peninsula (Venice: Giunta, 1499/1500) is relatively straightforward (Example 1). ${ }^{35}$ There are no repeated melodic phrases, although the descending gestures $b-a$ and $c$ - $a$ do reoccur. The verse constantly undulates towards and away from the notes

\footnotetext{
${ }^{33}$ Gillion, 'Shall the dead arise', 73-77; Gillion, 'Cantate Domino', 170-76; 179-81.

${ }^{34}$ This group is also referred to as Dominus dixit, from the incipit from the First Mass of Christmas. In this article, the group will be referred to as Ostende after the first appearance of the chant. On the nomenclature see: Willi Apel, Gregorian Chant (Bloomington, 1958), 381-82; David Hiley, Western Plainchant: A Handbook (Oxford, 1993), 132-33; James W. McKinnon and Christian Thodberg, 'Alleluia' in Grove Music Online (http://www.oxfordmusiconline.com). Accessed 21.04.2017.

${ }^{35}$ Copy consulted: GB-Lbl, IC 24240. The guidelines governing all the transcriptions and their subsequent analyses are found in the editorial method at the end of this article.
} 
$b$ and $c .{ }^{36}$ In addition to the jubilus that follows the word 'alleluia', the chant has three extensive melismas. The first (Melsima One) is a melodic elaboration that occurs on the word 'tuam' and cadences to $G{ }^{37}$ The second (Melisma Two), that falls on 'tuum', is the lengthiest and most elaborate in the verse. It exploits the chant's full range of a seventh, and features a quasisequential descending pattern that closes on $F$. The terminal melisma (Melisma Three) is more modest in scope, but does include a hint of repetition, as the cadential formula can resemble that used in the jubilus. ${ }^{38}$ As part of the earliest layer of the alleluia repertory, the melody of Ostende nobis was used with a number of different texts. ${ }^{39}$ By the sixteenth century, eight of these appeared regularly in Italian printed graduals (Table 1). The recurrence of the Ostende melody throughout the liturgical year facilitates an exploration into the editors' awareness of the chants' interconnectedness.

The modified Ostende alleluias in key printed graduals demonstrate that their editors' methods of revision were more systematic, and their knowledge of the repertoire deeper, than

\footnotetext{
${ }^{36}$ In his analysis of Alleluia Dominus dixit, Hiley observes that the verse in his exemplar (Paris, Bibliothèque nationale de France, lat. 776, fol. 12r), has the melodic goal of $c$. Hiley, Western Plainchant, 132. In Giunta $1499 / 1500$, there is equal emphasis on $b$.

${ }^{37}$ In referring to pitches, the following conventions are used. The lowest note of the medieval gamut is represented as $\Gamma$. From there the pitches ascend through uppercase letters $(A-G)$, lowercase letters $(a-g)$, and where necessary lowercase plus prime

${ }^{38}$ Hiley, Western Plainchant, 132. Hiley's exemplar notates paired phrases at the close of the terminal melisma. These do not appear in Giunta 1499/1500. In this printed source, Melisma Three is the most melodically unstable, and is shortened in many chants.

${ }^{39}$ McKinnon and Thodberg, 'Alleluia'; Karlheinz Schlager, Alleluia-Melodien I bis 1100; Monumenta Monodica Medii Aevi, Band VII (Kassel, 1968), 137, 368, 637-38.
} 
previously thought. In the versions from Gardano 1591, Giunta 1596, and Medici 1614/15, the eight chants, to greater or lesser extents, remain recognizably related. Analyses reveal that trends towards certain types of changes can be found in each source, which counteracts any initial impressions of haphazardness. The correspondences in the revised chants could thus result from the use of favoured revision techniques, combined with prioritization of certain aims, and guided by aesthetic considerations. Yet the similarities could also stem from editorial awareness of the chants' interconnectedness, and an effort to retain these relationships. The dissimilarities that exist between the alleluias do not necessarily mean the editors were unaware of the shared elements, but could represent their intentional rejection in favour of increased individuation. The modifications to the Ostende alleluias also demonstrate that, guided by their overarching plans and priorities, the editors approached the task of revision in a flexible fashion. They could — and did — work on a chant-by chant basis. They also could — and did — revise chants in groups; the two working styles were not necessarily exclusive. Their editorial efforts resulted in rich and intertwined printed plainchant repertoires, where pre-existent relationships were preserved and creatively reimagined.

[Example 1. Alleluia Ostende in Giunta 1499/1500 (ed. Francis of Bruges).]

Table 1. Ostende-type alleluias in Italian printed graduals.

\begin{tabular}{|l|l|}
\hline Alleluia & Possible liturgical designations \\
\hline Diffusa est gratia & Saint Lucy; Common of a Virgin \\
\hline Dominus dixit & First Mass of Christmas \\
\hline Dominus in Sina & Ascension \\
\hline Dominus regnavit exsultet & Third Sunday after Epiphany \\
\hline
\end{tabular}




\begin{tabular}{|l|l|}
\hline Haec dies & Easter Saturday \\
\hline Nimis honorati & Saints Simon and Jude; Common of an Apostle \\
\hline Ostende nobis & First Sunday of Advent \\
\hline Specie tua & Commons of various female saints; Common of a \\
& Virgin \\
\hline
\end{tabular}

Gardano 1591 (Venice): Ludovico Balbi, Orazio Vecchi, and Andrea Gabrieli. ${ }^{40}$

When Angelo Gardano embarked upon the production of a revised Graduale Romanum, he sought out editors familiar with plainchant and with contemporary musical aesthetics. Their credentials are foregrounded in the volume's preface: Andrea Gabrieli (1532/3-1585), organist of Saint Mark's, Ludovico Balbi (c. 1545-before 1604), music director of the church of Saint Anthony of Padua, and Orazio Vecchi (1550-1605), canon of Correggio. Gardano claims that the three men worked studiously both together and separately to correct a multitude of errors. ${ }^{41}$ Gardano's assertions, as with those in any preface, must be treated with circumspection. It is difficult to assess how - and even if — the editors operated as a team. ${ }^{42}$ Gozzi has argued that

${ }^{40}$ Copy consulted: I-TRbc FSG 16 (Feininger Collection).

${ }^{41}$ Graduale Romanum (Venice: Gardano, 1591), fol. 2r: Quod quidem Graduale Romanum à multis praestantibus, et primarijs Italiae viris, musica praeditis, in cantibus ipsis planis eruditissimis, revisum fuit: et in primis à R.D. Andrea Gabriele in Ecclesia Divi Marci Venetiarum Organico; à R. Magistro Ludovico Balbio, in Ecclesia Divi Antonij Patavini Musices moderatore et à R.D. Horatio de Vecchijs Mutinensi Canonico Corrigiensi; à quibus omnibus coniunctim, et separatim summo studio, ac diligentia correctum fuit, et emendatum [...]

${ }^{42}$ This is especially the case with the contribution Gabrieli, who predeceased the volume by six years. Agee takes the appearance of Gabrieli's name in the preface as evidence that work on the gradual was already occurring in the 1580s. Agee, 'Ideological Clashes', 146. 
there is no musical evidence for forward planning, design, or teamwork. ${ }^{43}$ However, a number of revision techniques are used consistently throughout the gradual, which suggests that irrespective of editorial cooperation, they were guided by a shared plan and priorities. ${ }^{44}$ Longer textual phrases are created through the removal of pause lines, and the text underlay is clarified through careful positioning and the use of ligatures. Yet the transmission of 'proper prosody', where the stress accent is conveyed through the number of notes per syllable, was not a concern. When the chants are shortened, the structurally important opening and closing sections of phrases are frequently retained, and the intervening material removed. Where necessary, the reshaped melodic line is made more conjunct through the use of added notes. ${ }^{45}$ The editors' systematic use of preferred revision techniques, intimacy with the repertoire, and fairly methodical approach to the task is evident in their modifications to the Ostende alleluias.

The Ostende-type alleluias in Gardano 1591 maintain a strong connection, which can be attributed to the interlocking factors of proximity, methodical melodic excision, and textual considerations (Appendix One). The eight occurrences of the melody are clustered between Advent and Lent, the Easter season, and in the Common of Saints (Table 2). The influence of liturgical proximity on the editors is clear from their revisions to the alleluia and jubilus. In all the chants, the 'alleluia' is mostly unchanged when compared with earlier printed plainchant traditions. The largest modifications occur in Ostende nobis and Diffusa est gratia, where a short

\footnotetext{
${ }^{43}$ Gozzi, 'The Venetian edition', 41.

${ }^{44}$ As it is not possible to reconstruct the exact division of labour, the following discussion will simply refer to "the editors'.

${ }^{45}$ The characteristics of the revised chant in Gardano 1591, and in the two other graduals under consideration, are discussed in Gillion, 'Shall the dead arise', 65-80.
} 
segment comprising the movement towards and away from $d$ is removed. This creates a stepwise descent to $G$. The cadence to the final is preserved in most of the chants, and half also retain the leap of a fourth to begin the jubilus on $c$. This is essentially reversed in Dominus in Sina and Haec dies; their alleluias close on $c$, and the jubili begin on lower notes ( $G$ and $a$ ) respectively. Nimis honorati and Specie tua feature cuts at the beginning of their jubili, and thus their melodies also begin in the lower register. The correspondences between the pairings appear to stem from their proximity. In the print, only seven leaves separate Dominus in Sina and Haec dies, while 15 separate Nimis honorati and Specie tua. ${ }^{46}$ Yet contiguity did not guarantee complementary revisions, as demonstrated by the identical changes in the distant Ostende and Diffusa. The influence of proximity was further tempered by the editors' aims and techniques.

Table 2. Ostende-type alleluias in Gardano 1591.

\begin{tabular}{|l|l|l|}
\hline Alleluia & Liturgical assignment & Location in gradual \\
\hline Ostende nobis & First Sunday of Advent & fol. 3r \\
\hline Dominus dixit & First Mass of Christmas & fol. $13 v$ \\
\hline Dominus regnavit & Third Sunday after Epiphany & fols. $28 v$ \\
\hline Haec dies & Easter Saturday & fols. $98 v-99 r$ \\
\hline Dominus in Sina & Ascension & fol. $105 v$ \\
\hline Diffusa est gratia & Saint Lucy & fol. $144 r-v$ \\
\hline Nimis honorati & Common of an Apostle & fol. $177 \mathrm{v}$ \\
\hline
\end{tabular}

${ }^{46}$ It is not possible to compare this with their physical proximity in the editors' exemplars, as these are unknown. Agee has proposed that the editors might have had access to the manuscripts revised by Palestrina and Zoilo. Gillion has shown that a gradual following the 1580 Liechtenstein tradition was mostly likely used as one of their sources. Agee, 'Ideological Clashes', 145-46; Gillion, 'Retrofitting plainchant'. 


\begin{tabular}{|l|l|l|}
\hline Specie tua & Common of a Virgin Martyr & fol. 192v \\
\hline
\end{tabular}

The editors' preference for a certain type of melodic excision could serve to reinforce the relationships between the Ostende alleluias. The three melismas are approached relatively uniformly. The preceding melodies, which are less dense in texture, are either left unchanged or are lightly altered through the removal of reiterated notes or repeated gestures. In the melismatic passages the editors tend to keep some of the opening and closing material, which can contain important modal signifiers. They then remove all the notes that fall between, or select several to form part of the reconstituted phrase. This technique is evident in the revisions to Melisma One. Between three and six notes are kept from the start of the melody and a similar amount is kept from its close, with all the material falling between removed. As the first melisma is the shortest of the three, this can result in a rather small cut. This is the case in Diffusa est gratia, in which the melisma is presented almost without change. Again, the chants can be divided into groups based upon their correspondences. The physically distant Dominus in Sina, Nimis honorati and Specie tua are revised identically, while the more proximate Dominus dixit and Dominus regnavit differ by only two notes. Ostende nobis and Haec dies are bound by the breadth of their cuts; the entire melisma is removed save for the cadential gesture. The modifications to the first melisma not only demonstrate the shifting importance of proximity. They also highlight how the same technique could strengthen the relationships between some chants, while simultaneously diminishing those between others.

The connections between the members of the chant family could also be reconfigured based upon textual considerations. The editors were not always concerned with grammatical accentuation; however, they were sensitive to phrasing and could be influenced by syllabification, as in Melisma Two. Most of the chants transmit the opening unchanged or lightly 
revised, and after a cut reconnect the melody at $b($ flat $) .{ }^{47}$ In Ostende nobis, Dominus in Sina, and Diffusa est gratia there follows a stepwise decent to $G$ before a brief cadential gesture and close on $F$. The words that are set in these three chants are all bi-syllabic, with a strong first syllable and a weak second: 'tuum', 'duxit', and 'Deus'. The melismas in Specie tua, Dominus dixit, and Nimis honorati all occur on words or word groupings that are three syllables or greater: 'prospere', 'hodie', and 'confortatus est'. The latter two chants feature a descent from $b$ (flat) through $a$ to $F$ (and in Nimis honorati, a return to $G$ ), gestures which occur near the beginning of the unrevised versions of the melisma. Their use increases the emphasis on the accented syllables of text. Specie tua features a longer cut, and is one of two chants that does not use a variant of the $b(f l a t)|a| G-F$ movement. The texts of Dominus regnavit and Haec dies consist of single words: 'laetentur' and 'exultemus', respectively. In the unrevised versions the melodic material preceding the melisma, which in the other chants is used for different words, is subsumed into Melisma Two. This is reflected in the revisions to Dominus regnavit and Haec dies, which are modified identically for the first half. They differ in the amount of cadential material kept: in the former, the stepwise descent from $b(f l a t)$ is retained, whereas the latter closes simply on $F$. The revisions to Melisma Two are thus clearly linked to the similarities between textual phrases, in this instance irrespective of the chants' proximity in the gradual.

Connections between the Ostende alleluias can be traced even in the musical diversity of the revised chants. The terminal melisma is approached in the least uniform fashion. The opening and closing gestures are variously truncated and the melody reshaped with notes from the central portions of the passages. The same extended cadence is used in Ostende nobis, Dominus dixit,

\footnotetext{
${ }^{47}$ Accidentals are not uniformly notated in Italian printed graduals, and as such will not be discussed in the analyses.
} See the editorial method. 
Dominus regnavit, and Specie tua, while a shortened figure is used in the other chants. The construction of the final phrases of Dominus dixit and Dominus regnavit is identical. This is achieved partly by similar cuts, but more significantly by the addition of notes to the latter chant. The notes $G$ and $F$ are added to the final two syllables on 'insulae', and an ascending third from $a$ to $c$ is interpolated into the melisma on 'multae'. The added notes are indicative of an attempt to make the two passages uniform. When the revisions to the Ostende alleluias in Gardano 1591 are considered in their entirety, it is evident that the editors were aware of the connections between the chants. The proximity of chants within the body of the gradual led to their similar modifications. Some congruencies also stemmed from a propensity towards a certain type of melodic excision. Yet the identical amendment of melismas located variously throughout the gradual lends weight to the assertion of editorial awareness of the chants' relationships. Modifications resulting from text make it clear that the editors approached the chants both as part of an interconnected family, and as individual pieces. The editors of Gardano 1591 combined a knowledge of the repertoire with methodical approaches and preferred revision techniques to creatively reshape the relationships between the Ostende alleluias.

Giunta 1596 (Venice): Anonymous. ${ }^{48}$

The firm of Giunta was the most prolific and powerful producer of liturgical chant books in early modern Venice. At the close of the fifteenth century, it brought out its first edition of the

\footnotetext{
${ }^{48}$ Copy consulted: D-As, 2 Th Lt K 26.
} 
Graduale Romanum (1499-1500), edited by a Franciscan friar, Francis of Bruges. ${ }^{49}$ Over the next 150 years, the firm issued nineteen further editions of the gradual, which was nearly three times the number of their closest competitor. Due to the framework of interrelation, the melodies in the Giuntine graduals formed the basis of a series of intertwined printed plainchant traditions, influencing the firms of Porris (Turin), Liechtenstein, Varisco, Ciera, and Baba (Venice).${ }^{50}$ Chant revision occurred in the editions of the Graduale Romanum issued by Giunta, but after the collaboration with Francis of Bruges, editors were generally not named. ${ }^{51}$ Therefore, it is not known who was responsible for drastically altering the plainchant melodies in the firm's 1596 edition. The structure and contents of the volume indicate that the editor's main exemplar was probably the collaborative Graduale Romanum published by Giunta, Varisco, and Paganinis in 1586. ${ }^{52}$ The revised plainchant reveals a strong aesthetic vision, which is embodied in the Ostende alleluias. The melodies are shortened by extensive excision and reconstructed through the addition of notes, while the text underlay is altered often, but not always, in favour of improved prosody. The Ostende alleluias embody these characteristics and exhibit increased individuation. However, due to certain editorial decisions they remain identifiable as a group, even if they were not necessarily approached as one.

\footnotetext{
${ }^{49}$ Mary Kay Duggan, Italian Music Incunabula: Music and Type (Berkeley, 1992), 129-42; 200-72; Sonia Carli, 'Il Graduale Romano curato da Francesco De Brugis, incunabolo di Lucantonio Giunta (1499-1500)' in Cattin, Curti, and Gozzi (eds.), Il canto piano nell'era della stampa, 201-5; Giuseppe Massera, La 'Mano musicale perfetta' di Francesco de Brugis delle prefazioni a corali di L.A. Giunta (Florence, 1963).

${ }^{50}$ Gillion, 'Shall the dead arise', 67-8 ff.; 'Retrofitting plainchant'.

${ }^{51}$ The exceptions are abbreviated editions of the gradual issued in 1546 and 1560, which were edited by Pietro Cinciarino of Urbino, a member of the Congregation of Blessed Peter of Pisa (the Hieronymites).

${ }^{52}$ Gillion, 'Diligentissime emendatum'; Gillion, 'Cantate domino', 163-64; Gillion, 'Retrofitting plainchant'.
} 
The editor of Giunta 1596 maintains unity within the chant family by leaving the alleluia and jubilus largely intact, before proceeding to increasingly extensive cuts (Appendix Two). This tendency is not restricted to the Ostende group, but can be seen in other alleluia chants throughout the gradual. The editor apparently found value in retaining their characteristic openings, perhaps due to their importance in the chants' performance. There were various methods of singing the responsorial chant, based upon locale and period, but the verse was always preceded and followed by at least one iteration of the alleluia and jubilus. ${ }^{53}$ Their melodies are presented almost without change in Diffusa est gratia, with a single $a$ added to the cadence of the alleluia, and a reiterated $b-a$ gesture removed from the jubilus. In a similar fashion Ostende nobis, Dominus dixit, and Haec dies are only lightly revised. In the remaining chants a small segment is excised near the centre of the alleluia, comprising the rise to $d$, and an extra $b$ is added to create a repeated $b$ - $a$ gesture. As the verse begins, the melodies begin to be stripped back. In the approach to Melisma One, the melodic focus is on its preceding notes, $b$ and $c$, which are kept in seven chants. The majority of the melisma is cut, and the text moved to the cadential gesture. Ostende nobis and Haec dies are the exceptions, as their syllables are divided between the rising $b-c$ gesture and a truncated cadence. In this fashion, the strong opening connections between the Ostende alleluias gradually diminish as the chants progress.

The strength of the editor's overarching aesthetic is evident in his revisions to the second melisma. These are mostly uninfluenced by proximity (Table 3) or prosody, although grammatical accentuation is generally conveyed. The editor favours excising the melismas' central portions; however, in a number of chants he reconfigures the melodies through multiple excisions and additions. This can be seen in Nimis honorati, where the added notes form roughly

\footnotetext{
${ }^{53}$ Hiley, Western Plainchant, 130; McKinnon and Thodberg, 'Alleluia'.
} 
parallel movement between the second and third syllables of 'confortatus': $[+c]-b-c|[+a]-G| a$. In Dominus dixit, the text is repositioned so that the word 'hodie' begins on a falling $c$ - $a$ gesture that originally preceded the melisma. The editor then selects a portion from its centre that he reconnects to an extended cadential gesture. The same central segment, save for one note, is used in Specie tua on 'prospere'. The next word, 'procede', is set with notes from the second half of the melisma and is followed by a significant cut. In so doing, the editor rejects the original closing notes for both 'prospere' $(F)$ and 'procede' $(a)$, and instead cadences the passage to $G$. Most drastically, the melisma in Dominus in Sina is cut almost entirely save for three notes, and closes on the modal final instead of $F$. As they forestall the forward movement of the phrases, the cadences on $G$ in Specie tua and Dominus in Sina disrupt the musical and textual syntaxes. The modifications to the second melisma indicate that the editor approached each separately, guided mainly by aesthetic considerations, which resulted in increased individuation.

Table 3. Ostende-type alleluias in Giunta 1596.

\begin{tabular}{|l|l|l|}
\hline Alleluia & Liturgical assignment & Location in gradual \\
\hline Ostende nobis & First Sunday of Advent & fol. $2 r-v$ \\
\hline Dominus dixit & First Mass of Christmas & fol. $10 r$ \\
\hline Dominus regnavit exsultet & Third Sunday after Epiphany & fol. 20r \\
\hline Haec dies & Easter Saturday & fol. $70 r$ \\
\hline Dominus in Sina & Ascension & fol. $75 r$ \\
\hline Diffusa est gratia & Saint Lucy & fol. $102 r$ \\
\hline Nimis honorati & Common of an Apostle & fol. $128 r-v$ \\
\hline Specie tua & Common of a Virgin & fol. $141 v$ \\
\hline
\end{tabular}


The connections between the Ostende alleluias, which decrease over the course of the verse, increase somewhat towards its end. This is due to the more uniform revision of the terminal melisma. The editor makes a single substantial cut from the central segment in six of the eight chants. In Specie tua and Nimis honorati, the line is reshaped through multiple excisions, and a greater number of notes are retained near the close. More expansive cadential figures are also used in Haec dies and Dominus dixit. Following the final phrase, the repeated alleluia—but not its jubilus - is notated for all chants except Haec dies. ${ }^{54}$ This is atypical in Italian printed graduals; in all previous sources its repetition is implied. The omission of the jubilus led Karp to argue that it was not sung a second time.${ }^{55}$ However, it is possible that the choir closed the chant with a full performance of the alleluia and jubilus, even if the latter was not notated. The inclusion of the ambiguous second alleluia highlights the complexity of the editor's revisions to the Ostende alleluias. Given his anonymity, his familiarity with the repertoire can only be gauged through his modifications to the plainchant. His musical literacy is displayed in his plans and priorities, which involved shortening and reworking the chant melodies. The diversity evident in the verses implies that he worked on a chant-by-chant basis, and was either unaware of or rejected their formulaic elements. Yet his decision to leave the opening of the chants largely untouched, whether accidentally or intentionally, renders the Ostende alleluias still distinguishable as a group.

\footnotetext{
${ }^{54}$ The text underlay of the word can differ, but in most of the chants the melody is that of the first iteration. The exceptions are Ostende nobis and Diffusa est gratia, which have slight variants.

${ }^{55}$ Karp, Post-Tridentine, 1:88, 103.
} 
Medici 1614/15 (Rome): Francesco Soriano and Felice Anerio. ${ }^{56}$

The Roman attempt to produce a revised Graduale Romanum spanned a twenty-year period and involved a number of composers. After a failed venture in the 1590s, Giovanni Battista Raimondi of the Stamperia Orientale Medicea revived the project in 1608, receiving a 15-year privilege from Pope Paul V. ${ }^{57}$ A six-man committee of musicians, suggested by Raimondi, were appointed to oversee the work. By 1611, only two members remained: Francesco Soriano (1548 or 15491621) and Felice Anerio (ca. 1560-1614). They completed the work several years later, with the Temporale published in 1614 and the Sanctorale in 1615. The gradual lost papal support just prior to printing, and although the privilege remained, was never universally imposed ${ }^{58}$ Despite its illustrious provenance, it had a limited influence on contemporary printed plainchant traditions. ${ }^{59}$ Further, some elements of its production remain obscure. The contributions of the larger committee (if any) are unknown. It is tacitly assumed that Anerio and Soriano were largely responsible for the revisions, although their division of labour is unclear. There is currently no evidence of the exemplars they used. As former choirboys turned clerics, they were obviously

\footnotetext{
${ }^{56}$ Copies consulted: I-TRbc FSG 19 and 20 (Feininger Collection); Baroffio and Sodi, facs. ed.

${ }^{57}$ The papal privilege provided the publisher exclusive rights to print the work during a limited period.

${ }^{58}$ For a detailed account of the Medicean Edition's long gestation period see Hayburn, Papal Legislation, 38-64. Transcription of the documents cited by Hayburn are found in Molitor, Nach-Tridentinische Choral-Reform, 1:296-7, 301-4, and 2:213-37.

${ }^{59}$ Karp, Post-Tridentine Mass Proper, 1:8, 86, 202. The Medicean Edition did influence the editor of the Graduale Romanum issued by the Venetian firm of Ciera in 1621; it was one of the (at least) four exemplars used. Gillion, 'Retrofitting plainchant'.
} 
well-acquainted with the plainchant corpus and also would have had access to local sources. ${ }^{60}$ As active composers, both were aware of contemporary theoretical precepts and aesthetic trends. Their knowledge of the repertoire and current musical concerns are reflected in the revised chants, which display a desire for clarified modality, increased brevity, and improved prosody, even to the point of partial re-composition. Their modifications to the Ostende alleluias demonstrate that, while aware of the chants' interrelation, they did not always choose to preserve it.

The editors' concern for modal clarification is evident at the beginning of the chants. All of the alleluias are altered to begin on the modal final, $G$ (Appendix Three). In most instances this is accomplished by the removal of the initial $F$, but in Diffusa est gratia and Specie tua the note is retained and prefaced by $G$. The rest of the melody is presented without alteration in Ostende nobis, and is only lightly revised in the other chants. The changes to the jubili are minor, but some occur consistently. The initial reiterated $c$ is removed in all of the chants. Further, in every chant except Haec dies, the $F \mid a-b-c$ figure is altered to a simple rising triad from $F$ to $c$. In the first cluster of Ostende alleluias, the gesture then falls to $G$ by means of an added $a$ to approach the cadence. Two basic cadences are used (with some slight variants). The first consists of a movement from $a$ to $b$-flat and a stepwise descent to $G$; the second of a simple oscillation between $a$ and $G$. The emphasis on modality carries into the verse, the beginning of which is altered in all the chants to begin on $G$. The editors' concern with modal clarity, combined with

\footnotetext{
${ }^{60}$ Soriano was the maestro di cappella of the Cappella Giulia (the papal chapel) between 1603 and 1620. Noel O’Regan, 'Soriano [Suriano, Suriani, Surianus], Francesco' in Grove Music Online; Klaus Fischer, 'Anerio, Felice' in Grove Music Online (http://www.oxfordmusiconline.com); both accessed 04.02.2019.
} 
their decision to revise the beginning of the Ostende alleluias relatively lightly re-creates an initial interconnection that can dissipate during the verses.

Soriano and Anerio's free approach to the melodic material is seen particularly clearly in their revisions to the melismas. These are reshaped through a combination of multiple small cuts, the addition of notes, and the repositioning of the text underlay. In each instance, they focus on a melodic cell retained in the majority of the chants, which is then elaborated upon in various fashions. For the first melisma, the editors work with the broad outline of the opening figure $a$ - $G$ $b-c$. This can be altered slightly by the interpolation of an $a$ after the $G$ (as in Dominus regnavit, Haec dies, and Specie tua), or the removal of the upper notes (as in Dominus regnavit, Nimis honorati, and Haec dies). Differing amounts of material is excised before the melody is reconnected to a cadential gesture. Exceptionally, in Dixit dominus and Dominus in Sina, the entire melisma is removed except for a brief cadence. The retention of the melodic cells unifies the Ostende alleluias on a structural level, while the surrounding variation increases their individuation. The modifications to the first melisma seem to stem solely from the editors' desire to reshape the melodies; however, those to the second can be connected to considerations of prosody.

The importance of the entwined relationships between textual and musical syntaxes are reflected in the treatment of Melisma Two, and highlighted in the editors' treatment of the shared three-note cell $(b|a| c)$. It is retained in six of the chants, followed by various excisions and a cadence to $F$. In Dominus dixit, this gesture forms part of a small melisma on the unaccented second syllable of 'ego'. This results in a relatively unusual instance of ungrammatical accentuation. After a large cut, the next word, 'hodie', appears on an extended cadential figure. The melodic cell does not appear in Dominus regnavit and Haec dies. In a similar fashion to the revisions in Gardano 1591, the differences in these chants could be due to the fact that their text 
phrases consist of a single word each. Multiple melodic excisions are used in Haec dies to create a brief melisma on the penultimate syllable of 'exultemus' before a single-note close on $F$. Anerio and Soriano create a more dramatic setting for 'laetentur' in Dominus regnavit, which might be an instance of text-painting. ${ }^{61}$ The melody rises joyfully to $e$, extending the range of the phrase upwards by a third, before ending on $c$. This not only eliminates the original melisma entirely, but also disrupts the syntax by its close to the subfinal. Further syntactical destabilisation occurs on Specie tua. The editors keep 'prospere procede' as a unit by ending the former word on $a$ to ensure the phrase's forward movement. Soriano and Anerio's understanding of musical grammar thus contributed to their creative revisions.

The modified Ostende alleluias in the Medicean Edition reveal the editors' deep knowledge of the repertoire, their awareness of the contemporary musical aesthetic, an overarching plan, and favoured revision techniques. The resulting individuation indicates an intentional rejection of the chants' formulaicism in favour of change. This is underscored in their alterations to the terminal melisma. Anerio and Soriano generally retain its first three notes, $b-c$ $a$, as well as a simple two-note cadential gesture. The text underlay of the phrase is altered so that the final syllable of the last word falls on the final two notes of the chant. ${ }^{62}$ The $b-c$ - $a$ gesture is not used in its entirety in Dominus dixit, Haec dies and Specie tua. The reason for its truncation is unclear. The latter two chants feature extended cadences; however, the cell is shortened differently in each instance. In the majority of the Ostende alleluias, the notes retained from the melismas are incorporated into the preceding melodic material to create different, expansive

\footnotetext{
${ }^{61}$ Text-painting (where the melody reflects the meaning of a word) occurs periodically in the Medicean Edition. Karp, Post-Tridentine, 1:204.

${ }^{62}$ The exception to this is Ostende nobis, where the final syllable of the last word falls on a single $G$.
} 
phrase shapes. The revised members of the chant family retain some structural unity in the midst of their newfound diversity. Yet the variety and extent of the changes suggests that the editors worked on a chant-by-chant basis, and that any resultant similarities were incidental. Closer examinations of two members of the chant family nuance this view.

The majority of the Ostende alleluias occur only once in the course of the Medicean Edition; however, Diffusa est gratia and Specie tua occur multiple times in the propers for various female saints (Table 4). ${ }^{63}$ The recurrences of these chants provide further insight into the editorial processes that went into the gradual. Diffusa est gratia is notated for the feasts of Saint Lucy, Saint Mary Magdalene, and Saint Anne, all of which occur in the second volume. The latter two versions differ from the melody used for Saint Lucy, which follows the outlines of the other Ostende alleluias (Example 2). The three chants open with the same reading of 'alleluia', but proceed to different jubili. In the versions used for Saint Mary Magdalene and Saint Anne, it opens with a rising $c$ - $d$-e figure that descends sequentially until it cadences to $G$. This melody is also used for the chants' final phrase, which was a common compositional device in medieval alleluias. The significant differences between the Diffusa est gratia alleluias point to at least two possible scenarios. Firstly, in order to make the two chants conform to a certain compositional style, an editor could have decided to alter them. This would explain the fact that the alleluias and the verses (save for the final phrases) remain unchanged. Secondly, the differences could stem from the exemplar(s) that were used. The geographical and conceptual distances between chant

\footnotetext{
${ }^{63}$ In most Italian printed graduals, the chants are notated on their first occurrence, and for all subsequent occasions the user is directed back via the rubrics.
} 
revision projects in Rome and Venice did lead to the inclusion of different melodies. ${ }^{64}$ Regardless of the provenance of the alternate alleluia melody, the editors ensured that it was used for two proximate chants.

[Example 2. Variant melodies of Diffusa est gratia in Medici 1614/15.]

Table 4. Ostende-type alleluias in Medici 1614/15.

\begin{tabular}{|c|c|c|}
\hline Alleluia & Liturgical assignment(s) & Location in gradual \\
\hline Ostende nobis & First Sunday of Advent & 1: fol. $2 r-v$ \\
\hline Dominus dixit & First Mass of Christmas & 1: fol. $19 r$ \\
\hline Dominus regnavit & Third Sunday after Epiphany & 1: fol. $46 v$ \\
\hline Haec dies & Easter Saturday & 1: fol. $170 r$ \\
\hline Dominus in Sina & Ascension & 1: fols. $182 v-183 r$ \\
\hline Diffusa est gratia & $\begin{array}{l}\text { Saint Lucy } \\
\text { Saint Mary Magdalene } \\
\text { Saint Anne }\end{array}$ & $\begin{array}{l}\text { 2: fol. } 12 v \\
\text { 2: fol. } 118 r \\
\text { 2: fol. } 124 r\end{array}$ \\
\hline Nimis honorati & Saints Simon and Jude & 2: fol. $175 r$ \\
\hline Specie tua & $\begin{array}{l}\text { Saint Monica } \\
\text { Saint Praxedis } \\
\text { Common of a Virgin and Martyr } \\
\text { Common of Many Virgins }\end{array}$ & $\begin{array}{l}\text { 2: fol. } 63 v \\
\text { 2: fol. } 116 r \\
\text { 2: fol. } 234 r \\
\text { 2: fol. } 240 v\end{array}$ \\
\hline
\end{tabular}

${ }^{64}$ This is discussed in Gillion, 'Retrofitting plainchant'. The variant melody in the Medicean Edition does not match the alternate melodies for the 'diffusa est gratia' text given in Schlager, Alleluia-Meldoien, xv. It also does not yield any results when searched for on the Cantus Index: Catalogue of Chant Texts and Melodies (http://www.cantusindex.org; accessed 21.04.2017). 


\begin{tabular}{|l|l|l|}
\hline & Common of a Female Martyr, who was not a & 2: fol. 246r \\
Virgin & 2: fol. $247 r$ \\
As above, in Paschal Time & 2: fol. $249 r$ \\
Common of a Female Saint who was neither a & \\
Virgin nor a Martyr & 2: fol. $250 v-251 r$ \\
As above, in Paschal Time & \\
\hline
\end{tabular}

The influence of proximity was an important factor in the editors' approach to Specie tua. The chant is notated eight times within the Medicean Edition, the last six of which are within twentytwo pages. The melodies of the final six appearances are mostly identical, except for a reiterated note added to the word 'tua' on three occasions. Further slight variants occur in the first two appearances of the chant. ${ }^{65}$ This general uniformity changes for the last two words of the final phrase, and five different readings are transmitted. (Example 3). The melodies for the word 'regna' are quite similar with the exception of the version on fol.63v, which appears truncated when compared with the rest. The greatest instability occurs on the note(s) associated with the word 'et'. In the unrevised version of the melody, 'et' is allocated to a single $a$. In the Medicean Edition the word appears on the gestures $a-c \mid b-a$ (fol. 63v); $b-a$ (fol. 116r); G-a (234r); or with a single $c$ (fols. $240 v, 246 r, 247 r, 249 v$, and 250-251r). It is unlikely that the variants result from typesetter error, especially since they can be linked to the chants' proximity within the gradual. The revisions to Specie tua suggest that Anerio and Soriano encountered the chant afresh on

\footnotetext{
${ }^{65}$ In the Feast of Saint Monica, the beginning of the verse is slightly different, and in the Feast of Saint Praxedis a single $c$ is appended to 'procede'.
} 
every occurrence, but in the knowledge of the other version(s). ${ }^{66}$ The editors could thus approach related items of plainchant both as individual and as interconnected entities. This systematic yet flexible method was employed, to different degrees, in the Ostende alleluias by all of the editors under discussion. Influenced by their knowledge of the corpus, bounded by their aesthetic plans, and guided by their priorities, they revised and redefined the melodic relationships inherent in the repertoire.

[Example 3. Variant readings of 'et regna' from Specie tua in Medici 1614/15.]

\section{Conclusions}

The editors of early modern Italian printed graduals faced an enormous and, in many ways, unenviable task: to revise a large, diverse, and well-known corpus according to contemporary music-theoretical and aesthetic standards. A significant proportion of the chants they encountered were interconnected through the use of melodic formulas. These repetitive structures not only functioned as a mnemonic aid for singers, but were also an identifiable compositional characteristic when the chants containing them were considered as a group. The editors' treatment of formulaic chants has been used to gauge their knowledge of the repertoire and their approaches to revision. The musical diversity evident in the revised chants has led to the conclusions that the editors disregarded or rejected melodic relationships-if they were even aware of them — and worked on a chant-by-chant basis. Analyses of the entire family of Ostende

${ }^{66}$ This approach can be seen at other points in the gradual where there are multiple iterations of a chant melody. Gillion, 'Retrofitting plainchant'. 
alleluias in three important editions of the Graduale Romanum provides a fresh perspective. The melodies reveal that the editor(s) shared a broad set of aims which they prioritized differently, and carried out according to their own overarching aesthetic plans with favoured revision techniques. The variable combination of these elements necessarily resulted in increased individuation between the chants, yet they also contributed to their continued connection.

Modifications to the Ostende alleluias in graduals issued by Gardano (Venice, 1591), Giunta (Venice, 1596), and Medici (Rome 1614/15) reveal how the editorial process could maintain or re-create concordances within considerable melodic diversity. The editors of Gardano 1591 were composers and clerics who possessed intimate knowledge of the plainchant repertoire. Although the extent of their cooperation is unknown, a particular type of melodic excision is frequently used throughout the gradual. The consistent removal of a melisma's central portion ensured a continued connection between the Ostende alleluias. In addition, their tendency to revise chants in clusters based on location, or due to textual considerations, creates further moments of concordance. The anonymous editor responsible for Giunta 1596 was the most flexible in his approach. His free treatment of the melodic material combined with syntactical destabilization, weakens the relationships between the members of the chant family. However, his decision to only lightly revise the alleluia and jubilus - perhaps due to performative considerations - maintains an important bond between the chants and preexistent printed plainchant traditions. The Medicean Edition of 1614/15 was revised by musical and liturgical experts. Their amendments to the Ostende alleluias demonstrate the influence of contemporary theoretical precepts, especially concerning modal clarity and textual intelligibility. They also reflect compositional ingenuity through the retention and manipulation of shared melodic cells that serve to reconstruct musical associations between the chants. In all three sources the Ostende 
alleluias remain distinguishable as a chant family, although the relationships have, sometimes drastically, changed.

These findings underscore the challenges of assessing editorial intentions and methods from analyses of the revised plainchant. The increased individuation evident in the Ostende alleluias can obscure the editors' awareness of, and systematic approach to, the interconnected chants. There is a propensity to expect that familiarity with the repertoire and a consistent approach should result in similar revisions, and indeed, this is sometimes the case. There are indications that the editors were, at times, seeking to preserve the relationships between the chants. Correspondences could also arise from the regular use of certain revision techniques, guided by overarching aesthetics and prioritized aims. In one sense unintentional, these concordances still served to connect the chant family. Yet musical diversity does not necessarily negate knowledge and planning: dissimilarity could stem from the rejection of formulaic elements or the prioritization of other concerns. The revised Ostende alleluias thus illustrate that structural relationships could be retained and reinterpreted in the midst of sweeping melodic change. Further, they highlight the fact that, influenced by their plans and principles, the editors employed a flexible yet systematic approach to their work. They could revise chants as single entities and as groups; the two methods were not always exclusive. The editorial endeavours evident in early modern Italian printed graduals resulted in fascinating, multifaceted plainchant repertoires, the intricacies of which invite further exploration.

Marianne C.E. Gillion, KU Leuven marianne.gillion@kuleuven.be 


\section{Editorial Method}

The transcriptions in the examples and the appendices broadly follow the editorial conventions outlined by Karp in his study of early modern printed graduals, An Introduction to the PostTridentine Mass Proper. ${ }^{67}$ In order to facilitate the comparison of musical readings, the neumes appear simply as single note-heads, special notational signs that (potentially) related to rhythm and liquescence are not represented. ${ }^{68}$ Slurs are used to indicate ligatures and note-groupings. Accidentals are notated as they appear in the sources. It is important to highlight that accidentals were not uniformly notated in Italian printed graduals; ficta was often left to the common sense of the singers. ${ }^{69}$ Pause lines, which are important to the text-music syntax, appear as barlines. These can be of different lengths (whole-stave or half-stave) and justified either at the top or bottom of the stave. These aspects are retained. The spelling, capitalization, punctuation, of each source are transmitted, and the original text underlay has been followed as clearly as possible. In the three appendices, the Ostende alleluias are presented synoptically in the order that they appear

\footnotetext{
${ }^{67}$ Karp, Post-Tridentine, 2:ix-x.

${ }^{68}$ In this matter I differ from Karp. The three sources under consideration do not use liquescence in the chants, and possible rhythmic interpretations of the notation are not relevant to the analyses. On rhythm in early modern printed graduals see: 'Le edizioni liturgico-musicale dopo il concilio' in Danilo Curti and Marco Gozzi (eds.), Music e Liturgia Nella Riforma Tridentina (Trent, 1995), 39-55; Antonio Lovato, 'Aspetti Ritmici del Canto Piano nei Trattati dei Secoli XVI-XVII' in Cattin, Curti, and Gozzi (eds.), Il canto piano nell'era della stampa, 99-114.

${ }^{69}$ Due to this variance, accidental use is not commented upon in the discussion of the Ostende alleluias. Although a $b$-flat might not be notated in a chant, it could still have been sung in performance.
} 
within the source. ${ }^{70}$ Shared melodic material is presented vertically, as this helps to visually chart the changing relationships between the chants. The three melismas are indicated by boxed numbers on the transcriptions.

[Appendices]

Biographical Statement

Marianne C.E. Gillion is an FWO postdoctoral research in the Department of Musicology at KU Leuven on the project According to Antwerp, Reformed to Rome: Music, Liturgies, and Identities in the Bishopric of Antwerp (1559-1801). She was previously a research assistant on the project Music printing in German-speaking lands: From the 1470s to the mid-16th century at the University of Salzburg. Marianne's research interests include the use of plainchant in Reformation liturgies from German-speaking areas and in Counter-Reformation liturgies from Italy and the Low Countries.

${ }^{70}$ The exceptions, for reasons discussed in the article, are the readings of Diffusa est gratia and Specie tua from the Medicean Edition. The versions from vol. 2 fol. $12 v$ and fol. $234 r$ respectively are used in the synoptic transcription. 

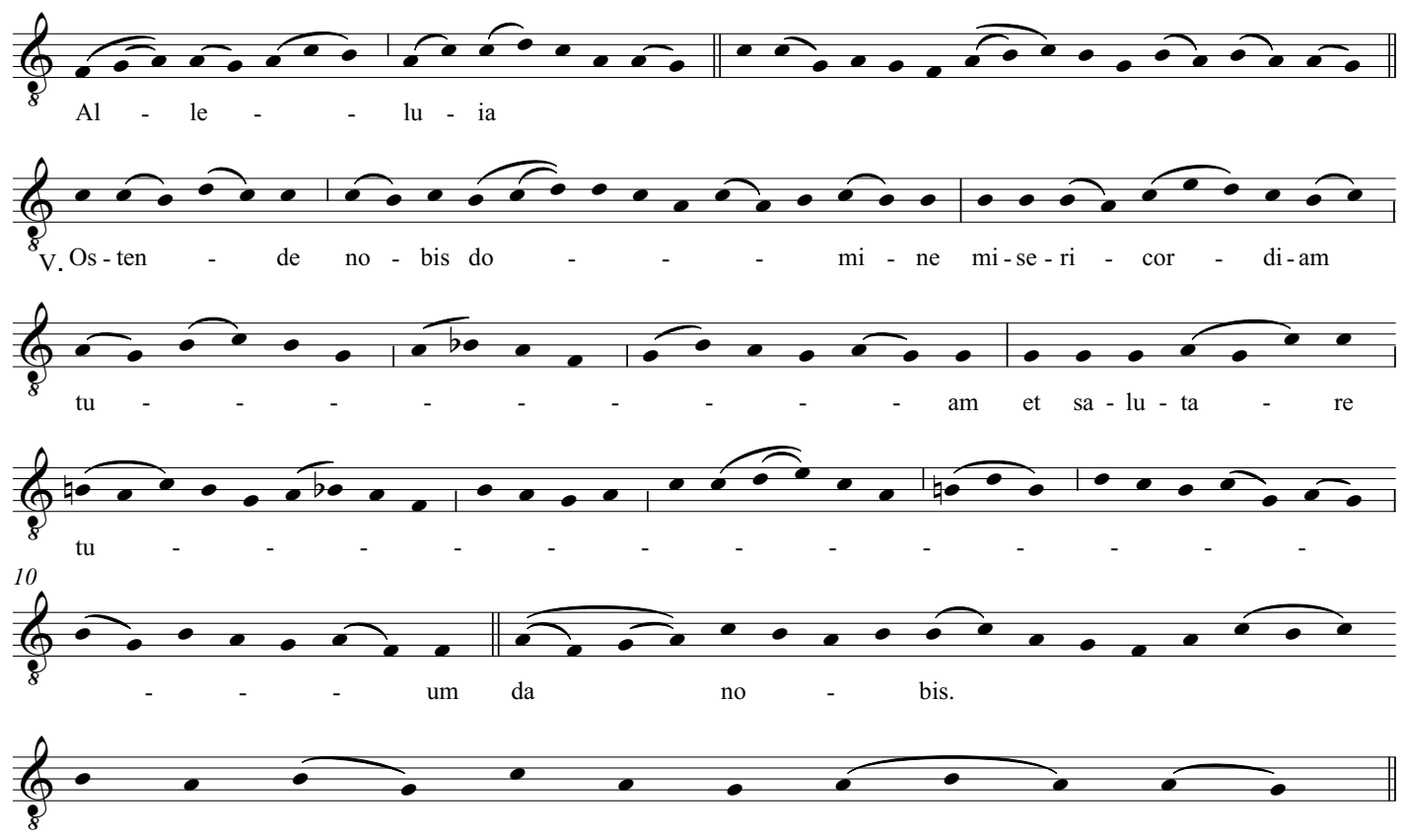
Example 2. Variant melodies of Diffusa est gratia in Medici 1614/15.
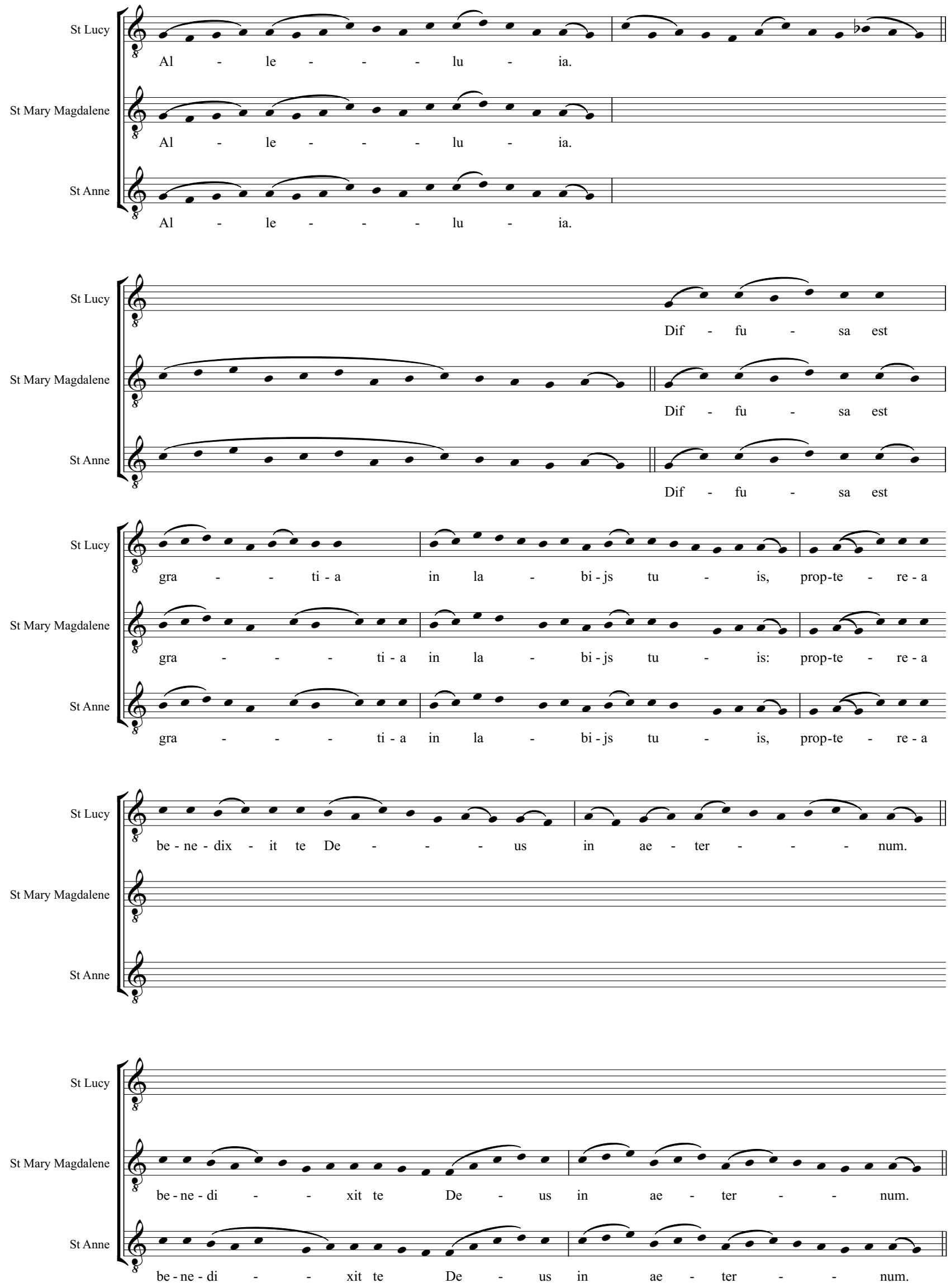
Example 3. Variant readings of 'et regna' in Alleluia Specie tua in Medici 1614/15.

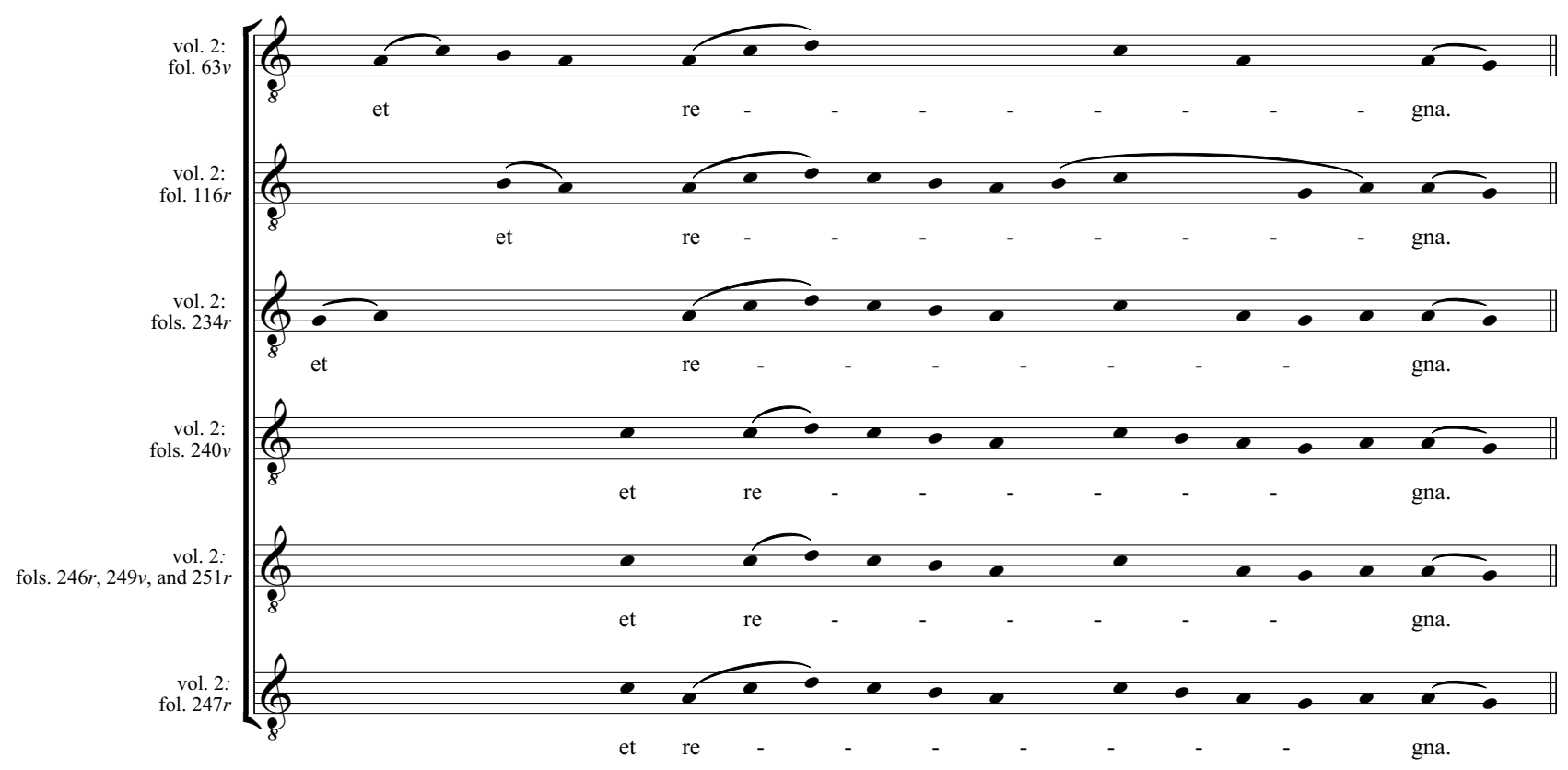


Appendix 1. Ostende-type alleluias in Gardano 1591 (Venice: eds. Ludovico Balbi, Orazio Vecchi, and Andrea Gabrieli).
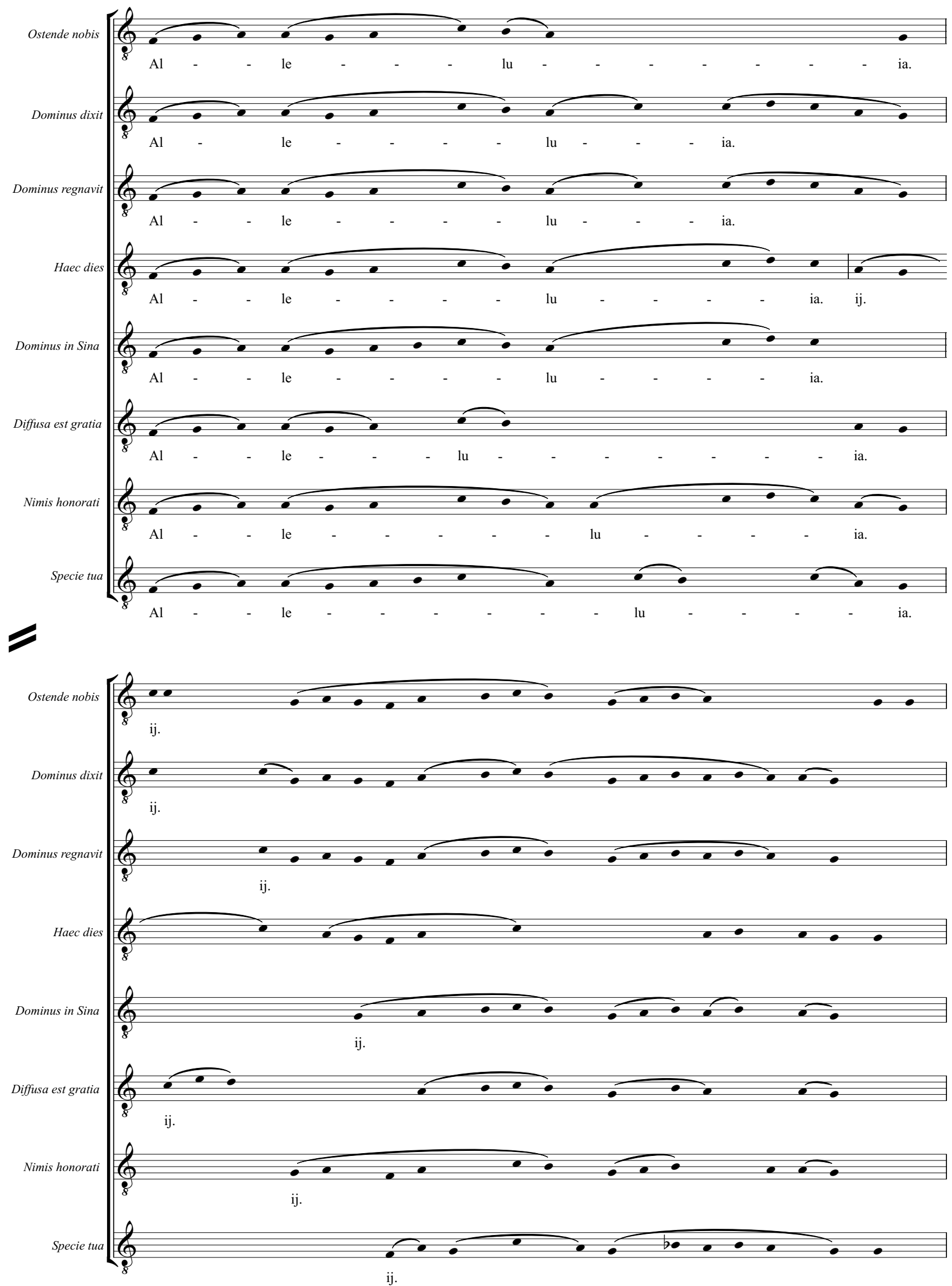

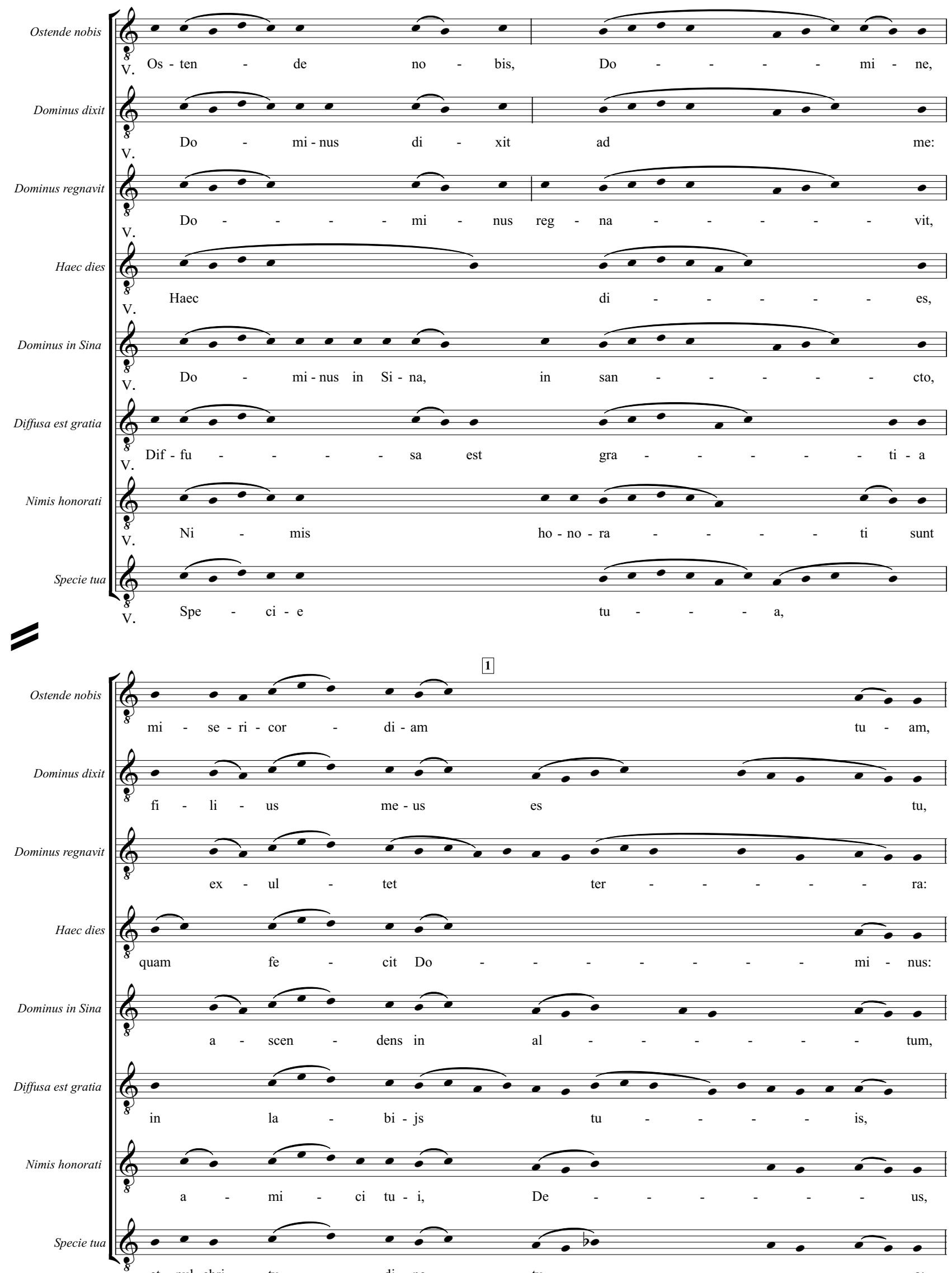

et pul-chri - tu - to di - ne

tu 

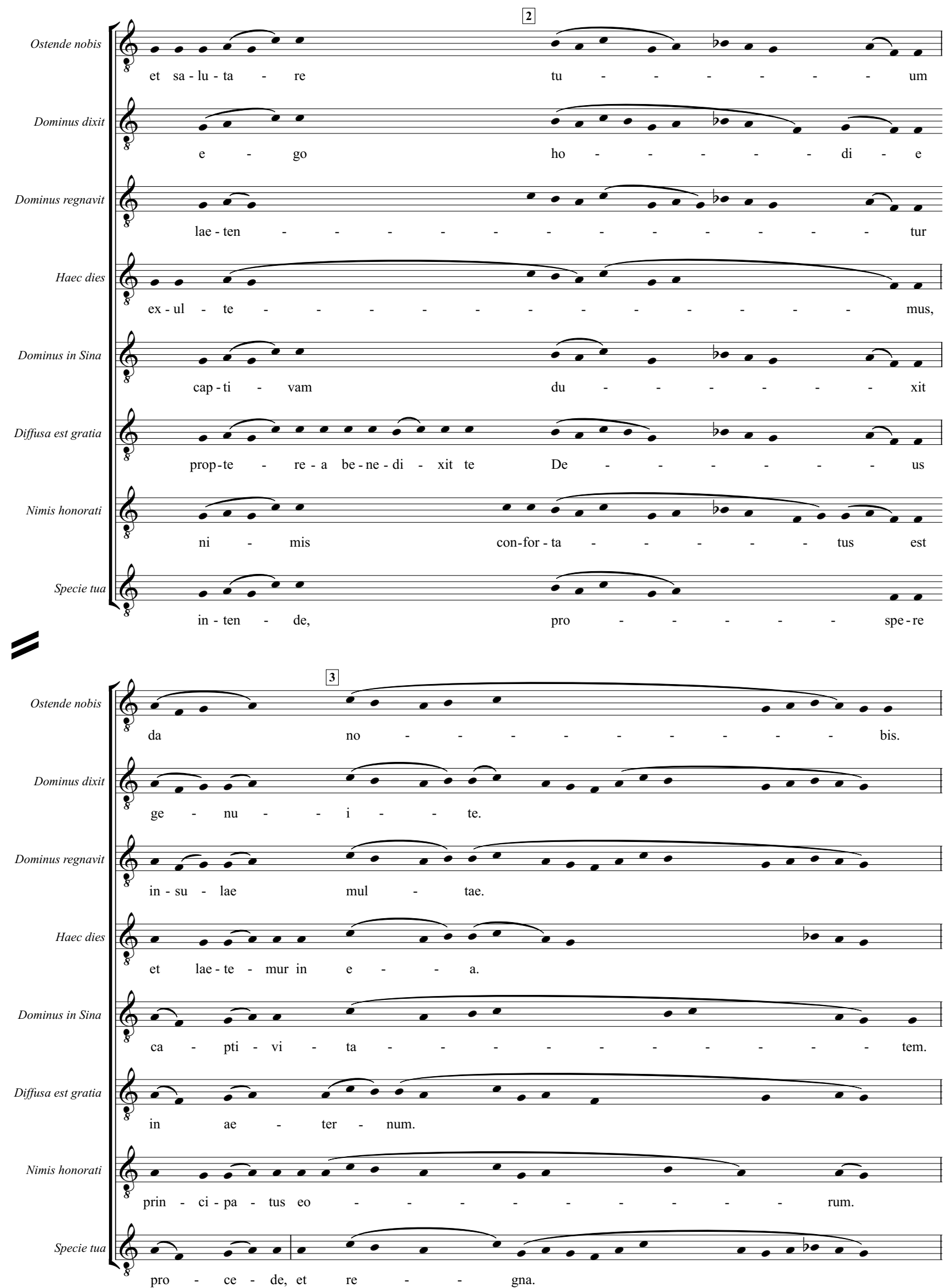
Appendix 2. Ostende-type alleluias in Giunta 1596 (Venice: anonymous editor).
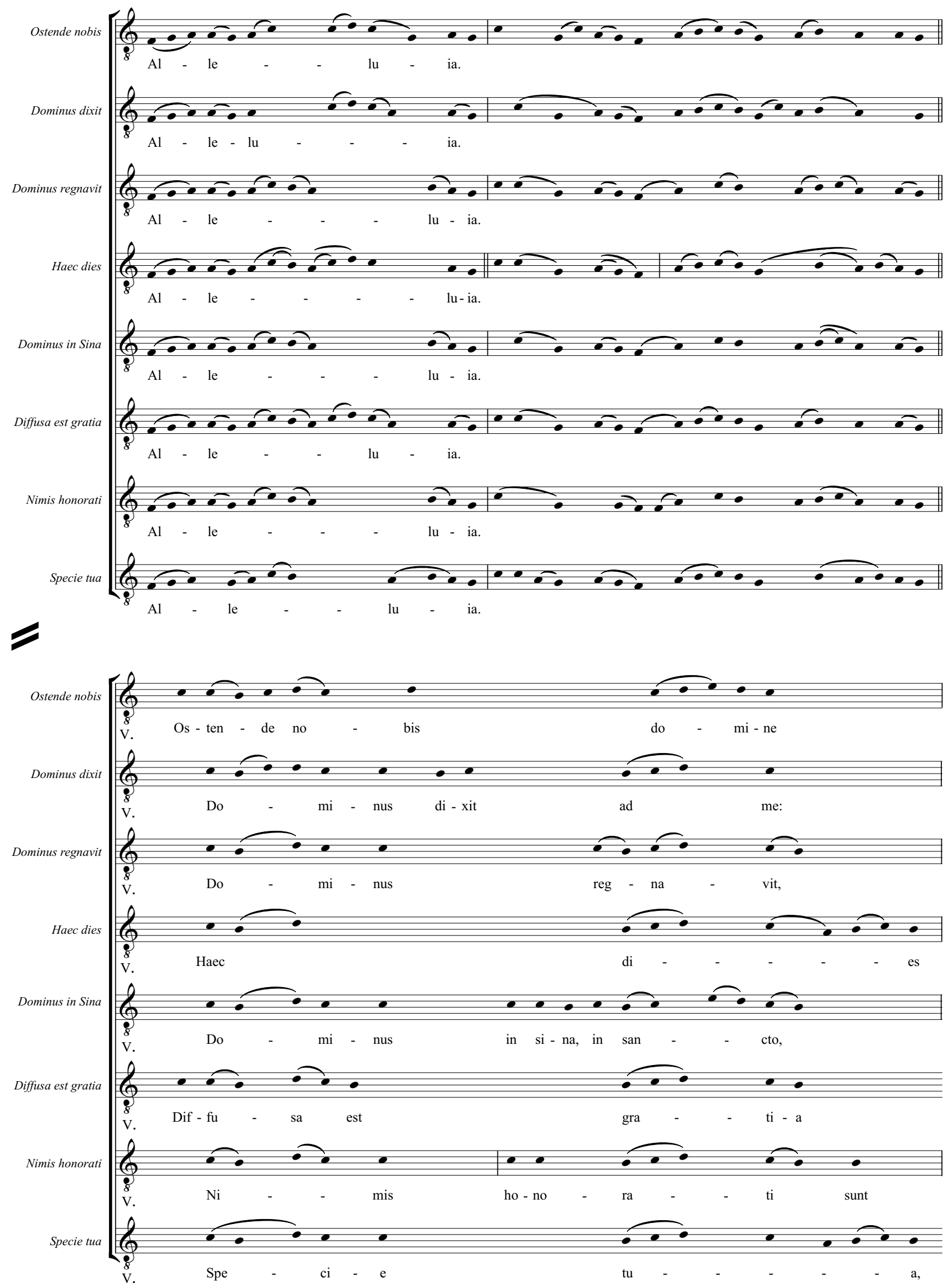


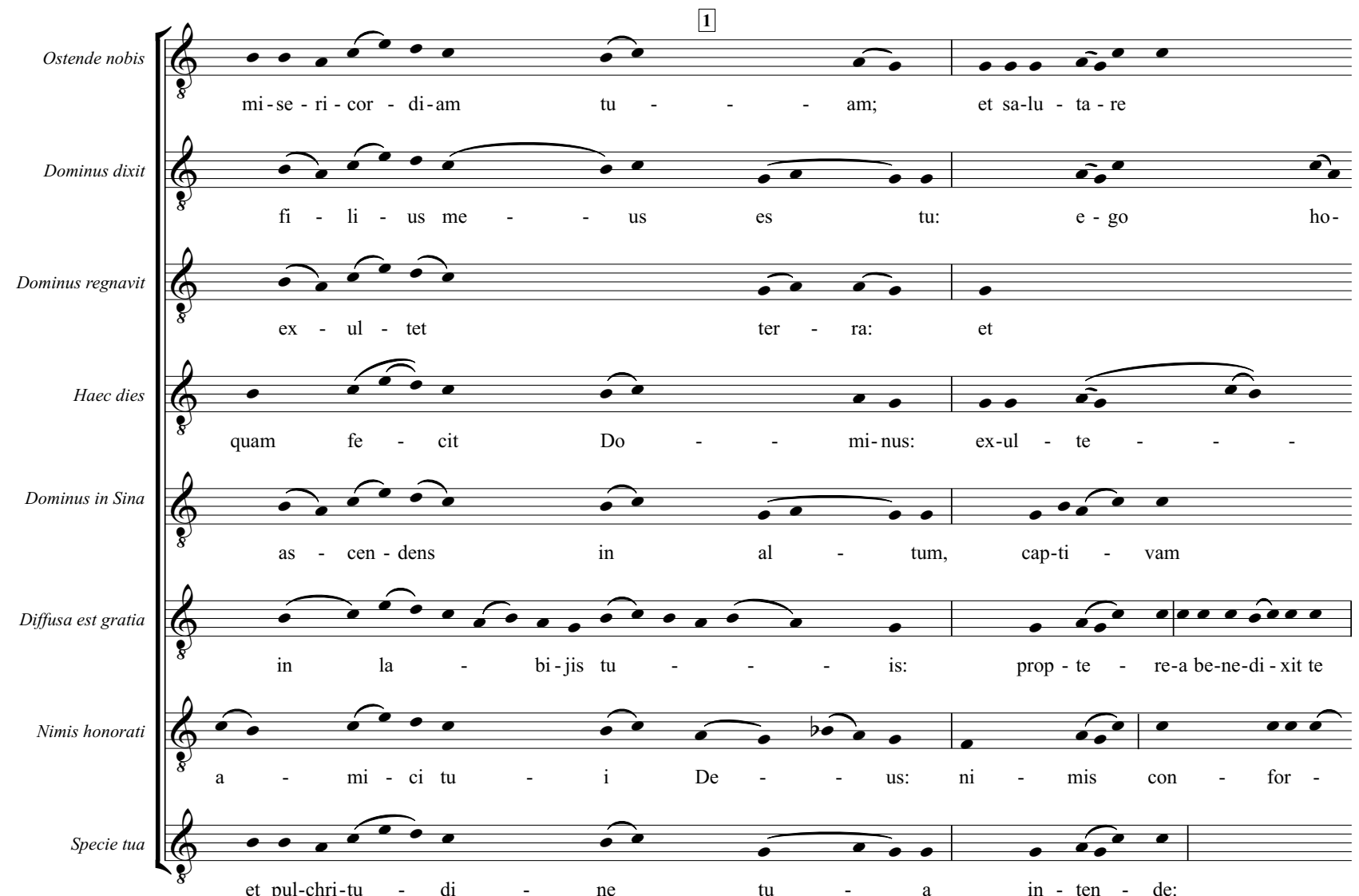

1

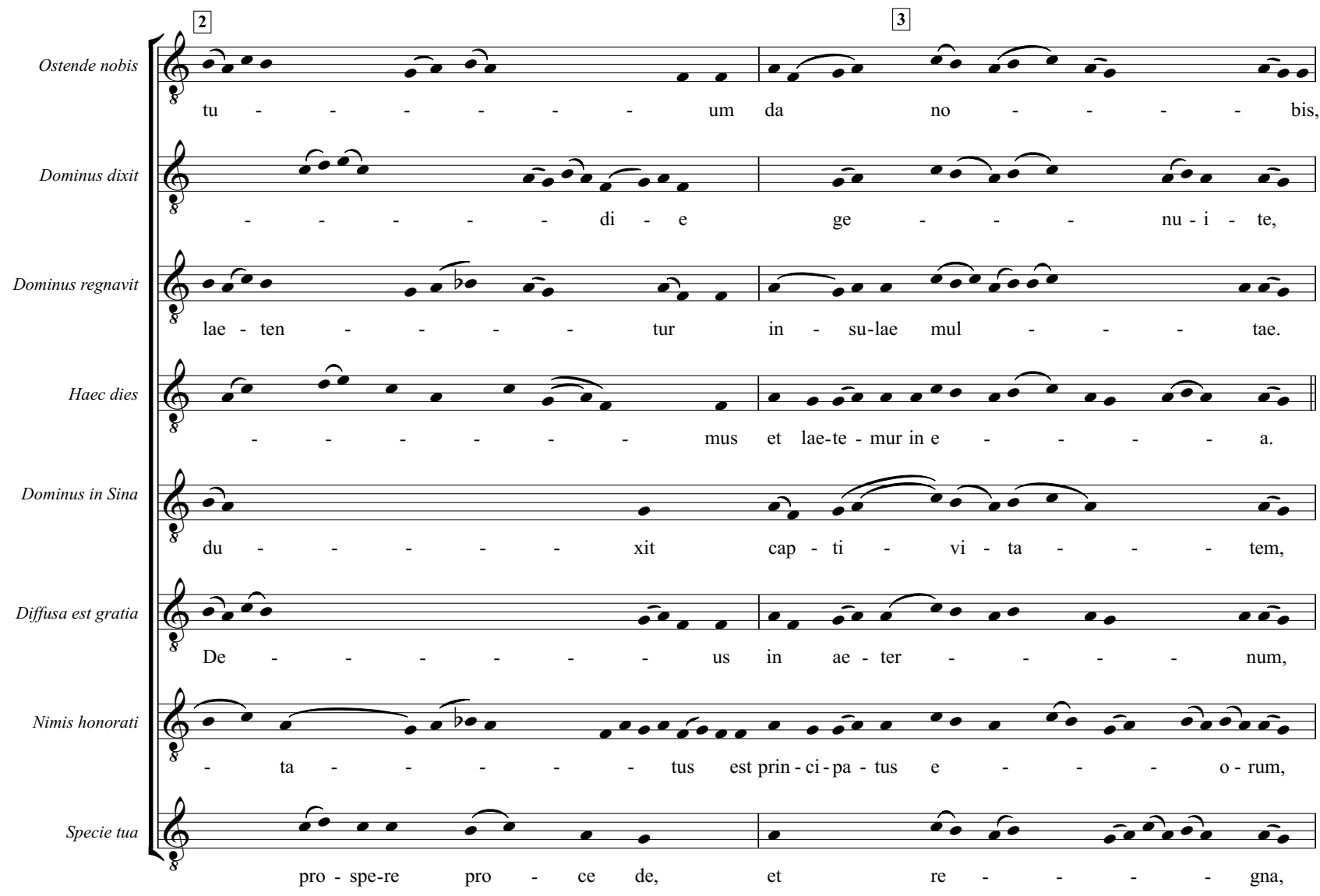




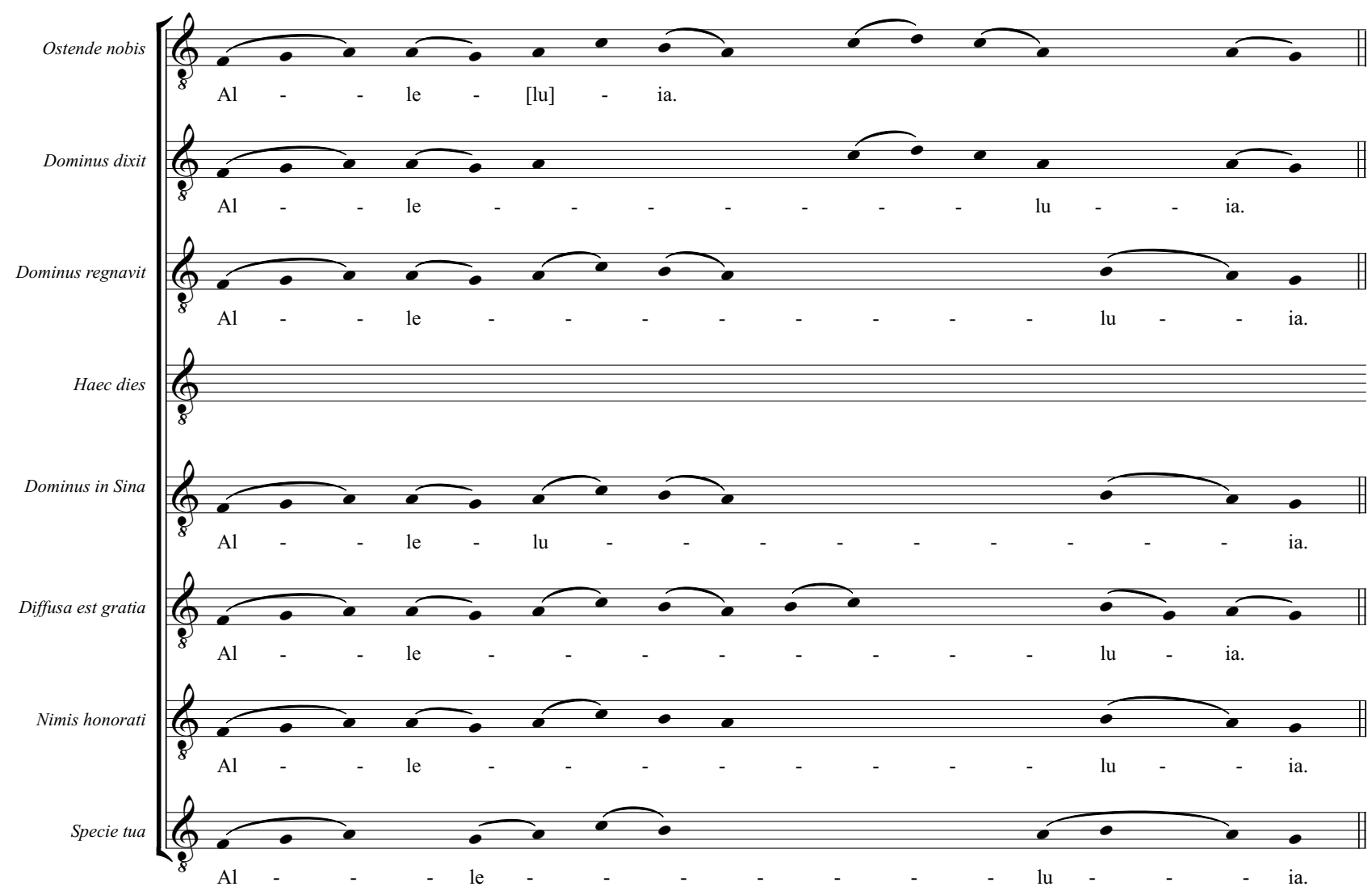


Appendix 3. Ostende-type alleluias in Medici 1614/15 (Rome: eds. Francesco Soriano and Felice Anerio).
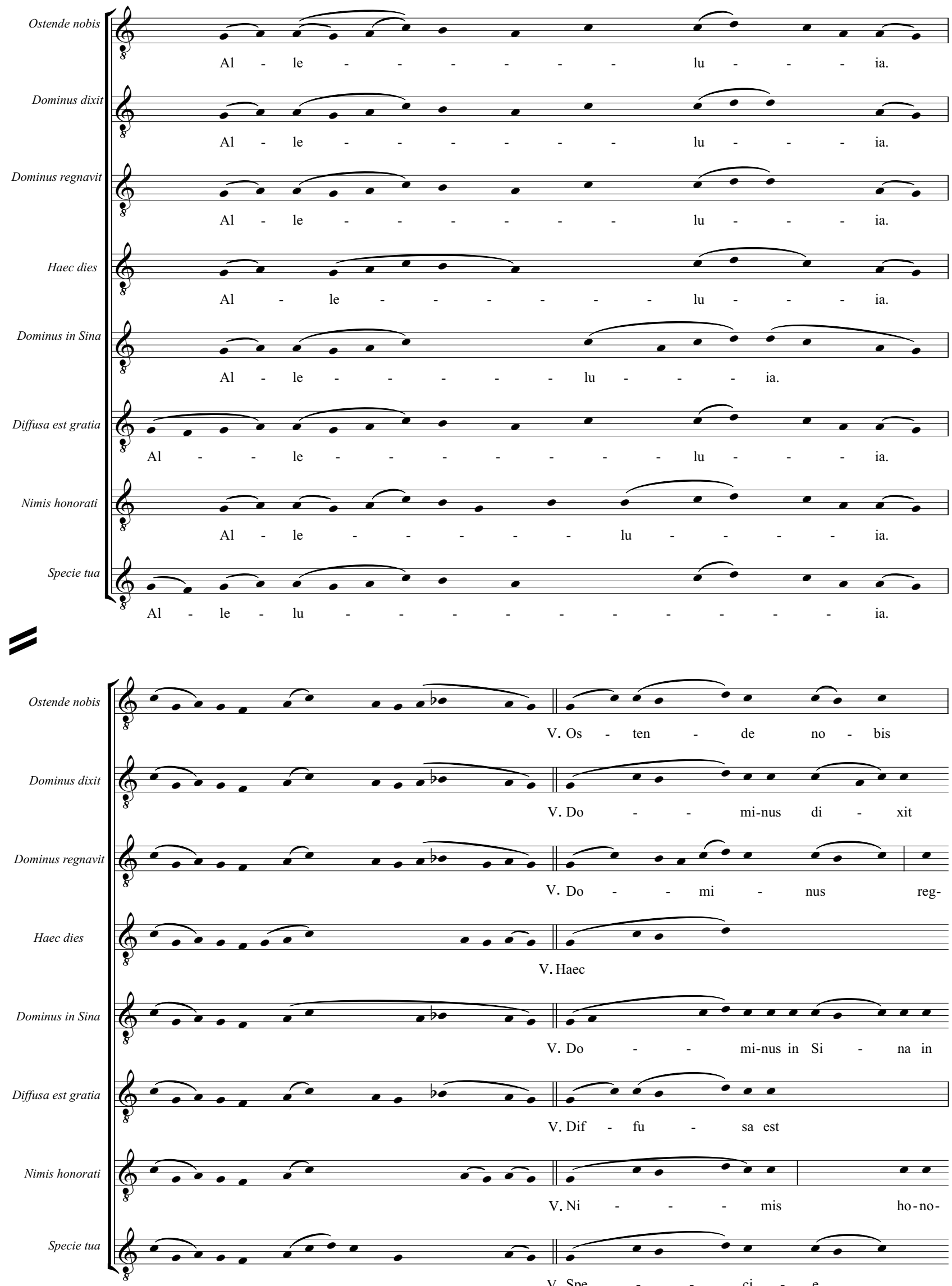

V. Spe 

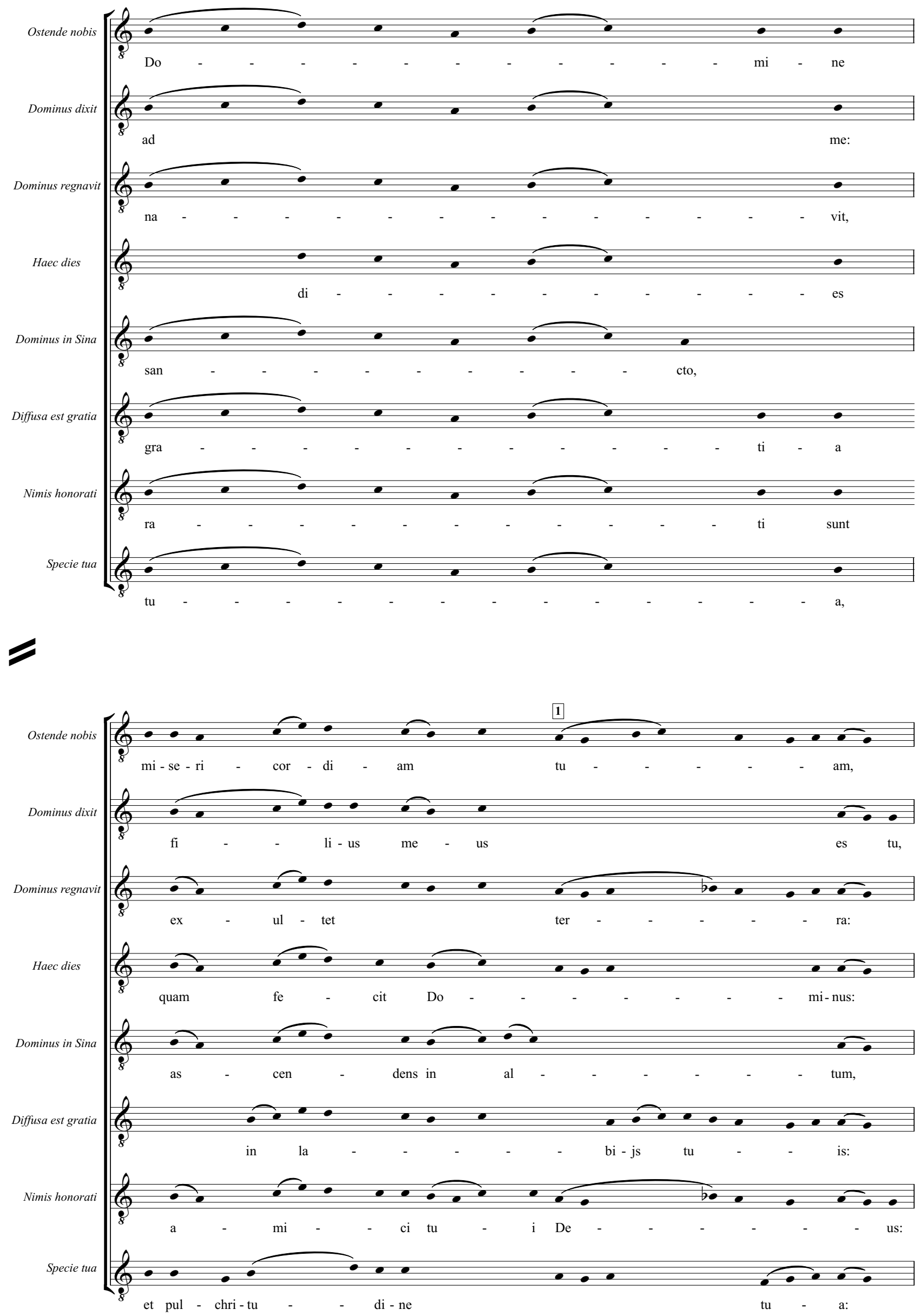

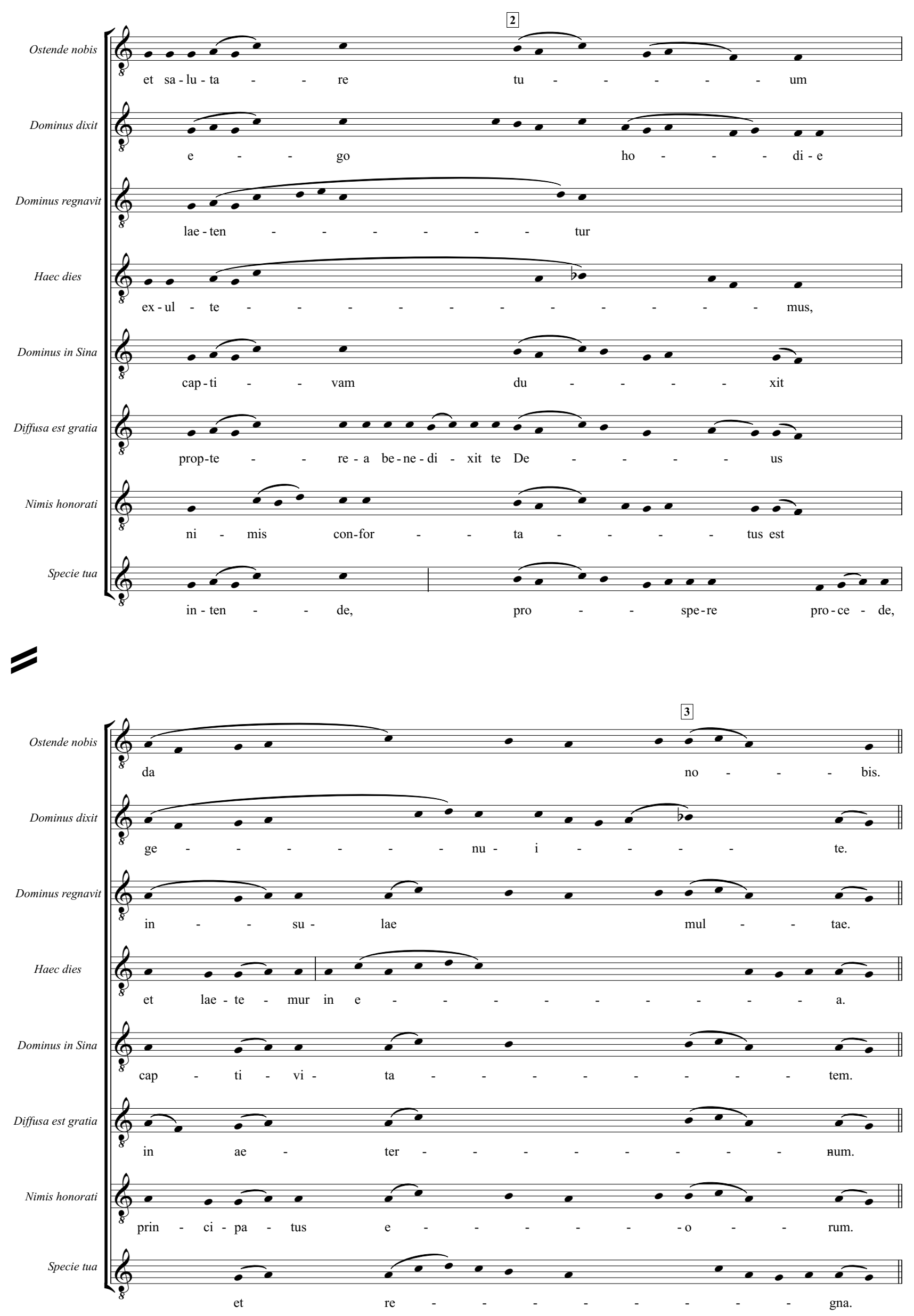